\title{
Labor Market Effects of Unemployment Insurance Design
}

\author{
Konstantinos Tatsiramos* and Jan C. van Ours ${ }^{\dagger}$
}

June 28, 2012

\begin{abstract}
With the emergence of the Great Recession unemployment insurance (UI) is once again at the heart of the policy debate. In this paper, we focus on the recent theoretical and empirical evidence on the labor market effects of UI design. We provide an overview of the design of UI in various countries and we discuss policy issues related to the structure of the UI system, including the pros and cons of a UI system in which the generosity of UI benefits is varying over the business cycle. Finally, we identify potential areas of future research on UI design.
\end{abstract}

Keywords: Unemployment insurance, unemployment dynamics, job search, labor market policy

JEL-codes: J64, J65, J68

\footnotetext{
*Department of Economics, University of Leicester and IZA; k.tatsiramos@le.ac.uk

${ }^{\dagger}$ Corresponding author; Department of Economics, CentER, Tilburg University, The Netherlands; Department of Economics, University of Melbourne, Parkville, Australia; CEPR, CESifo and IZA; vanours@gmail.com.
} 


\section{Introduction}

When workers lose their job for reasons outside their control they may be eligible for unemployment insurance (UI) benefits. Whether they are in fact eligible and how generous these benefits are depends on the design of the UI system. The main purpose of UI design is to provide the best balance between consumption smoothing and limiting adverse effects of incentives to work. Changes in the UI design happen quite frequently as response to changing economic conditions or on the basis of dissatisfaction about the previous design. With the emergence of the Great Recession, the labor market effects of UI are once again in the heart of the political debate (OECD, 2010). In the discussion both short-term and long-term perspectives of UI systems are important. The short-term perspective is related to the role of UI benefits in funding shorttime work arrangements to dampen the effects of the Great Recession, while the long-term perspective is related to the role of UI benefits over the economic cycle. As usual, the level and especially the maximum duration of unemployment benefits are also elements in this discussion.

In the past decade new theoretical and empirical studies have been published and the question is to what extent does this recent literature provides novel insights into the optimal design of UI. We provide an overview of recent theoretical and empirical evidence on incentives influencing the behavior of employed workers and UI recipients and discuss its implications for UI design. ${ }^{1}$ In our presentation and discussion we focus on the two main characteristics of a UI system, the level and maximum duration of benefits, but we also discuss eligibility and

entitlement conditions. We also provide a discussion of a UI system in which level and duration of benefits are varying over the business cycle. By focusing on the labor market effects of UI design we do not address the interactions between UI and other labor market institutions. ${ }^{2}$

The set-up of our paper is as follows. In section 2, we give an overview of theoretical and empirical studies on incentives related to unemployment insurance. Section 3 presents some stylized facts of labor markets in relation to unemployment and a brief description of the UI system in various countries. In section 4 we present relevant policy issues for the design of the UI systems derived from the literature overview in relation to the main characteristics of current systems. In the last section we provide concluding remarks on the design of the UI and we identify areas for future research.

\section{Incentives related to Unemployment Insurance}

UI provides unemployed workers with benefits in order to smooth consumption. However, at the same time UI may induce moral hazard. With UI an unemployed worker may search less intensively for a new job than she would otherwise do if no benefit was provided. The tension between insurance and incentives is at the heart of UI design.

Providing private unemployment insurance is problematic for various reasons. The first 
problem concerns asymmetric information. The worker has more information about her unemployment risk than the insurer. If an insurance company would establish the insurance premium on the basis of the average unemployment risk, the insurance will not be attractive for workers with a low unemployment risk. For a given insurance premium unemployment insurance is especially attractive for workers with a high unemployment risk. This causes adverse selection of 'bad' risks; the insurance company makes losses or has to increase the insurance premium. However, if unemployment insurance becomes more expensive it is even more unattractive for low risk workers. The obvious solution to this problem is that insurance companies select workers and do not allow high risks to enter or the company differentiates insurance premiums only offering high premiums to high risk individuals. Both solutions are often unacceptable from a societal point of view. While it mimics market insurance, collective unemployment insurance deviates from actuarial principles by charging premiums that do not reflect individual risks. Furthermore, unemployment risks are correlated and difficult to predict. In a recession many workers become unemployed at the same time. If recessions would be predictable they could be accounted for when establishing the UI premiums. However, the unpredictability of correlated events requires adjustments of UI premiums to avoid UI funds going bankrupt. Only the state has the power to enforce these adjustments. For all these reasons unemployment insurance is usually a mandatory and collective arrangement.

Numerous studies have analyzed various aspects of the functioning of the unemployment insurance system. Their findings show that thanks to its economy-wide risk-pooling, unemployment insurance enables a high degree of consumption smoothing (Gruber, 1997; Browning and Crossley, 2001), performs well under idiosyncratic, sectoral, and regional shocks, and acts as an automatic macroeconomic stabilizer. ${ }^{3}$ But studies also find that unemployment insurance creates reemployment disincentives by prolonging unemployment duration and contributing to higher equilibrium unemployment. However, the magnitude of disincentive effects is not a firmly established parameter, and the literature is inconclusive and rather thin on important aspects. To stimulate workers to search for a job several incentive mechanisms are introduced. These mechanisms can be grouped under three headings: sequencing of benefits, monitoring and benefit sanctions, and workfare (see also Fredriksson and Holmlund, 2006a and 2006b).

We focus on the incentive mechanisms which influence the outflow from the UI system such as level and duration of unemployment, and influence the inflow into unemployment such as eligibility criteria, while we ignore issues such as monitoring and benefit sanctions and active labor market policies. ${ }^{4}$ 


\subsection{Theory}

\subsubsection{Unemployment outflow}

\section{Partial Equilibrium Model}

The partial equilibrium search model has been central in studying the effect of unemployment benefits on the exit rate from unemployment. ${ }^{5}$ Unemployed workers choose a reservation wage which balances the costs and benefits of continued search and thus determines whether they accept or reject received offers. An increase in the benefit level leads to an increase in the reservation wage, which lowers the unemployment exit rate and increases the duration of unemployment. This behavioral response to more generous benefits has been interpreted as a moral hazard effect. Allowing for search effort as an additional choice for the unemployed job-seeker does not alter the main effect of benefit receipt. An increase of the benefit level not only increases the reservation wage but it also leads to a lower search effort, both of which affects the job-finding rate negatively.

Allowing for non-stationarity, in which the benefit level changes over the unemployment spell and benefit duration is limited, the main theoretical prediction is an increasing job finding rate over the spell of insured unemployment (see Mortensen, 1977; Van den Berg, 1990). When the UI system defines a declining profile of benefit payments or a benefit termination the instantaneous income declines over time leading to a reduction in the value of unemployment. The decline in the value of unemployment over the course of the unemployment spell leads to a drop in the reservation wage, which results in a higher exit rate close to benefit exhaustion.

In most UI systems, benefit entitlement depends on previous employment experience, which is in contrast to the assumption of the basic model that all unemployed receive benefits. Typically, new entrants in the labor market and long-term unemployed are not entitled to receive unemployment insurance. Finding a job for this type of unemployed means also becoming entitled to unemployment insurance in case they lose their job in the future. This entitlement effect increases the incentive to accept jobs for UI recipients close to benefit exhaustion and for those who are not entitled to unemployment benefits. The change in the behavior of job seekers over the spell of unemployment and the entitlement effect implies that individuals with different lengths of benefit entitlement would behave differently.

For a given length of unemployment and for a given level of benefits, an increase in the potential benefit duration will lead to a higher reservation wage, and consequently to a rise in the average duration of unemployment. The disincentive effect at the beginning of the unemployment spell is expected to be small. The largest effect of an increase in benefit duration is expected for unemployment durations close to the benefit expiration period because the reservation wage at that time will be significantly higher compared to the situation without a benefit extension, in which the reservation wage is at its lowest level. 
An increase in the benefit level will also affect unemployed workers differently depending on their elapsed unemployment duration. Contrary to an extension of the benefit duration, an increase in the replacement rate has its largest effect at the start of the unemployment spell. For a recent unemployed worker, an increase in the benefit level will lower the exit rate from unemployment as a result of a higher value of unemployment. The job seeker will demand a higher wage before accepting a job offer. For an unemployed close to benefit exhaustion, a higher benefit level will lead to a higher exit rate due to the entitlement effect.

Based on this simple version of the job search model, the overall effect of an increase in the generosity of benefits on the average duration of unemployment depends on the balance of two opposing effects. First, a higher amount of benefits and a longer benefit duration will lower the exit rate from unemployment. Second, for the non-eligible and for those close to benefit exhaustion, more generous benefits will create an incentive to find a job faster due to the entitlement effect. However, since the entitlement effect is second-order it is likely that the disincentive effect dominates so an increase in benefit generosity will lead to longer unemployment durations.

\section{Liquidity Constraints}

The shape of the effect of benefit level and potential benefit duration depends on the extent to which individuals are liquidity constrained. In the presence of complete credit and insurance markets, where consumption can be smoothed perfectly, an increase of UI benefits operates only through moral hazard and there will be no reason for the reservation wage to vary over the course of the unemployment spell. The moral hazard interpretation of longer unemployment duration in the presence of more generous UI ignores the role of liquidity constraints. Chetty (2008) suggests that the overall effect of a change in benefits on the search effort can be decomposed to a moral hazard effect and a liquidity effect. When individuals cannot smooth consumption perfectly an increase of UI benefits allows the unemployed to search longer without the pressure to find a new job quickly, which leads to longer unemployment duration. Shimer and Werning (2007) also challenge the moral hazard interpretation of individual behavior by arguing that the after-tax reservation wage measures the well-being of unemployed workers. Therefore, if increases of UI benefits raise the average after-tax reservation wage this would increase welfare. ${ }^{6}$

\section{Equilibrium Search Model}

The basic search model delivers predictions of the effect of UI on unemployment duration and on individual wages through its effect on the reservation wage and search effort. The equilibrium search model instead models both workers and firms decisions and considers equilibrium wages, which are derived endogenously (see Pissarides, 2000). In the original formulation of the model wages are determined through Nash wage bargaining, which is the mechanism that shares the 
rents created due to frictions between workers and firms. For both firms and workers the rents are the difference between what they could obtain through forming a match and the best outside opportunity. The sum of the rents creates the surplus to be shared. In this framework, an increase of unemployment benefits increases the value of unemployment for the job-seeker, which leads to an increase in their wage in the bargaining process. Since a higher wage lowers firms' expected profits, to restore equilibrium firms lower the average cost of vacancies by reducing the number of vacancies, which lowers labor market tightness, the ratio of the number of vacancies and the number of unemployed. An increase in benefits and the corresponding drop in labor market tightness leads to an increase in the unemployment rate.

The equilibrium search model with Nash bargaining has been challenged recently. Shimer (2005) shows that the standard search and matching model cannot explain the cyclical behavior of unemployment and vacancies, which are both highly variable and strongly negatively correlated in U.S. data. In addition, the model cannot explain the strong procyclicality of the job-finding rate. The main explanation for the failure of the model to fit the data is that wages are determined by Nash bargaining, which implies that wages respond flexibly to productivity shocks that hit the economy. A positive productivity shock, for example, increases job creation by firms opening up more vacancies, which leads to an increased job-finding rate and a lower unemployment rate. The increase in hiring, however, lowers unemployment duration raising workers' threat point in wage bargaining, which leads to a higher wage. This wage flexibility lowers employer's gain from the productivity shock eliminating the incentive for vacancy creation. As a result, fluctuations in labor productivity have little impact on the unemployment, vacancy, and job-finding rates.

This critique on the ability of the equilibrium search model to explain the business cyclicality of its key components (unemployment and vacancies) has led to suggestions of alternative wage determination mechanisms that generate more rigid wages. Hall (2005) offers an alternative in which real wages are determined by a social norm that does not change over the business cycle. Shimer (2005) suggests that countercyclical movements in workers' bargaining power could also allow for amplification of shocks in the economy. ${ }^{7}$

\subsubsection{Unemployment inflow}

Unemployment benefits may also affect the unemployment rate via a higher inflow from employment. There are different ways this might occur. First, in the equilibrium search model with an endogenous job destruction rate (see Mortensen and Pissarides, 1999) more generous unemployment benefits exert an upward pressure on wages, which makes jobs become unprofitable more quickly and be destroyed.

The benefit system may also affect the inflow into unemployment by changing the participation decisions of inactive individuals. Rather than being employed or unemployed, individuals 
may decide not to participate at all in the labor market. When unemployment benefits are paid only to active job-seekers, that is, inactive people do not receive the benefit, an increase in the generosity of benefits might increase aggregate labor force participation. The intuition is that the entitlement to higher income while seeking jobs induces more people to be engaged in active job search. Thus unemployment benefits may actually increase participation.

Finally, another way in which more generous benefits might affect the inflow into unemployment is by inducing individuals to quit more easily or induce a separation and claim unemployment benefits. Moral hazard may be problematic not only for unemployed workers but also for employed workers if it reduces their effort and thus increases the probability that they will be fired (Karni, 1999). ${ }^{8}$

\subsubsection{Post-unemployment outcomes}

Unemployment insurance may not only create disincentives in job search but may also affect post-unemployment outcomes. There are different potential mechanisms and relevant outcomes.

First, more generous benefits will have a positive effect on the re-employment wages. The intuition is that with higher benefits unemployed workers become more demanding in terms of the wages they are willing to accept. Ehrenberg and Oaxaca (1976) were the first to consider this effect.

Second, in a labor market with search frictions, benefits perceived as a subsidy for the unemployed to search for a suitable job tend to reduce job mismatch. When benefits are high, unemployed workers become more selective, and only accept jobs which are less likely to dissolve, and there is an increase in worker productivity growth (Marimon and Zilibotti, 1999). This leads to a trade-off between unemployment and mismatch, where more benefits increase the number of high-quality jobs in the labor market but unemployed workers experience higher unemployment with longer average duration. Acemoglu and Shimer (1999) show that even moderate UI encourages unemployed workers to apply for high-wage jobs with high unemployment risk and firms create those higher-quality jobs.

Unemployment benefits, therefore, might have an effect on job match quality through higher wages and employment stability. We discussed earlier that more generous benefits will increase the inflow into unemployment due to more firing by firms when a productivity shock reduces their profitability. To the extent that UI increases the quality of the match between workers and firms increasing their productivity, that might mitigate the effect of UI on the inflow into unemployment.

\subsubsection{The design of unemployment insurance}

If the search effort of unemployed workers could be observed and verified then there would be no moral hazard problem and the optimal design would entail full insurance with a constant profile 
of benefits over the unemployment spell. In the presence of moral hazard, the design of the UI system needs to consider the trade-off between consumption smoothing through insurance and incentives to search for work.

\section{Consumption Smoothing}

Hansen and Imrohoroglu (1992), focusing on the consumption smoothing and the disincentive effect of UI, show that even in the presence of moral hazard optimally designed unemployment insurance programs can yield positive welfare benefits. The utility gain of a UI through consumption smoothing has been empirically documented by Gruber (1997) who finds that benefit eligibility reduces the drop in consumption in the event of unemployment by one-third compared to what the drop would have been in the absence of UI.

\section{Benefit Profile}

A UI system with a declining sequence of benefits has been considered optimal in the presence of moral hazard because it provides stronger incentives to search (Shavell and Weiss, 1979; Hopenhayn and Nicolini, 1997; Pavoni and Violante, 2007). Most OECD countries have a system with declining sequence of benefits through a two-tiered UI system, in which workers who lose their jobs are entitled to UI benefits for a limited period after which they receive Unemployment Assistance (UA) benefits. The two-tiered UI system exploits the entitlement effect that was discussed above as it provides the incentive to search more actively for those who are close to benefit exhaustion and for those not-entitled to benefits (Fredriksson and Holmlund, 2006a).

Another mechanism to enhance the incentives to exit unemployment is to combine a declining sequence of benefits with a wage tax after reemployment, whereby the tax level depends on the duration of the unemployment spell. An increasing tax profile will encourage job finding by making prolonged search more expensive. In particular, the wage tax could be negative at the beginning of the unemployment spell representing a bonus for exiting unemployment quickly (Hopenhayn and Nicolini, 1997).

There are a number of theoretical considerations that are important regarding the optimal design of UI. When wages are determined through union-firm bargaining, a decreasing benefit schedule leads to wage pressure because it increases the welfare of the short-term unemployed at the expense of the long-term unemployed. When search effort is a choice of the unemployed worker, a declining sequence of benefits is needed to encourage job search but the incentive effect will be weaker due to the wage pressure effect (Cahuc and Lehmann, 2000).

When the choice of effort determines not only the job finding probability through search effort but also the probability of remaining employed through the choice of work effort, then the optimal UI system might be non-monotonic. In the beginning of the unemployment spell 
the system should induce a large drop in consumption in order to discourage shirking. This will affect the unemployment inflow. Benefits should increase initially and then fall throughout the spell (Wang and Williamson, 1996). The initial increase is similar to the re-employment bonus of a negative wage tax of Hopenhayn and Nicolini (1997) at the beginning of the unemployment spell followed by a declining sequence of benefits. Overall, the literature regarding the sequence of benefits suggests that a declining profile provides better incentives than a flat (or increasing) profile.

The literature discussed so far on the optimal design of UI has considered models in which the unemployment agency can affect the consumption patterns of the agents through the sequence of benefits. This rest in the assumption that the agents cannot save and borrow without constraints from the market. Recent research has allowed for borrowing and savings, which means that the employment agency cannot influence the consumption profile of the unemployed worker through a declining benefit profile (e.g. Chetty, 2008; Pavoni, 2007; Shimer and Werning, 2008). The optimal policy in this case is a constant benefit level that insures workers against unemployment risk, while their ability to dissave and borrow allows them to avoid transitory fluctuations in consumption (Shimer and Werning, 2008).

The optimality of constant benefits discussed above rests on the assumption of homogenous workers for whom the trade-off between insurance and incentives does not change over time. In the presence of duration dependence, when the job-finding probabilities deteriorate over the spell of unemployment, or when there is heterogeneity in the types of unemployed, the trade-off between insurance and incentives changes during the spell and the optimal benefits should also vary over time (Shimer and Werning, 2006). The exact profile of optimal benefits depends on the mechanism that drives duration dependence and on the form of heterogeneity. If job opportunities deteriorate over time because of skills depreciation, then declining benefits are optimal. This is because with constant benefits the long-term unemployed would have lower incentives to accept a job offer. If instead the unemployed receive fewer job offers over time, then increasing benefits could be optimal as the reason for remaining in unemployment is not because of an increasing reservation wage but because of lack of job opportunities. Similarly, the form of heterogeneity would dictate a different profile of benefits. A decreasing profile would be optimal if the pool of unemployed changes over time consisting of types with high value of leisure. On the other hand, benefits should rise during an unemployment spell if workers face higher uncertainty and higher variance in the wage draws they receive. This higher value of search is associated with a higher reservation wage and a longer unemployment duration, which could lead to a better job match if the unemployed is properly insured over time.

Tests of the Optimality of UI

Gruber (1997) uses the framework suggested by Baily (1978) to estimate the optimal level of UI 
benefits. The optimal level of benefits trades off the gains from consumption smoothing against the costs of search distortion. The gains are computed by the sensitivity of consumption to the replacement rate of benefits, while the costs by the elasticity of the duration of unemployment with respect to balanced-budget increases in UI benefits and taxes. The findings suggest that even at very high degrees of risk aversion, the optimal replacement rate is below 50 percent, while the average replacement rate in the data used in the study is 42.6 percent. Gruber (1997) also shows that the results are very sensitive to the magnitudes of the elasticity of unemployment duration used and the effect of the replacement rate on consumption smoothing.

Shimer and Werning (2007) develop a dynamic model of job search with risk aversion and find that a worker's utility while unemployed is a monotone function of her after-tax reservation wage, which implies that the objective of an optimal UI system is to choose benefits and taxes so that the after-tax reservation wage is maximized. Contrary to the consumption based optimal test proposed by Gruber (1997), the approach suggested by Shimer and Werning (2007) does not require an estimate of risk aversion or information on consumption. Instead their test uses information on how unemployment benefits affect the pre-tax reservation wage and on the elasticity of unemployment duration with respect to benefits. The drawback of this approach is that while there are many empirical studies on the elasticity of unemployment duration there is scarce evidence on the sensitivity of the reservation wage to unemployment benefits.

Chetty (2008) also provides a test for the optimal UI taking into account the two possible effects of unemployment benefits: the moral hazard effect and the liquidity effect. He finds that the liquidity effect accounts for 60 percent of the marginal effect of UI benefits on durations in the United States. This estimate implies that a replacement rate of 50 percent is near optimal that pays constant benefits for 6 months. To evaluate the optimality of UI the test requires estimates of three sufficient statistics: the duration of benefit receipt, the elasticity of UI-compensated duration with respect to UI benefit level, and the moral hazard and liquidity effect of benefits. Contrary to the studies by Gruber (1997) and Shimer and Werning (2007), the optimal level of benefit does not necessarily fall with the elasticity of UI-compensated duration with respect to UI benefit level. The result depends on whether an increase of benefits leads to longer duration due to a liquidity effect (which smooths consumption) or due to a moral hazard effect (which subsidizes leisure). In other words, a higher liquidity effect would imply that increases in benefit generosity would be welfare improving.

These three different ways to test for the optimality of unemployment insurance highlight the importance of obtaining precise estimates of key parameters such as the elasticity of unemployment duration with respect to unemployment benefits, the sensitivity of the reservation wage and consumption to benefit changes.

Optimal UI over the Business Cycle 
There are few recent studies on the optimal UI over the business cycle. Andersen and Svarer (2010) and Landais et al. (2010) find countercyclical optimal benefits. In Andersen and Svarer (2010) the government uses UI to smooth consumption over the business cycle facing an intertemporal budget constraint. Landais et al. (2010), instead, impose a balanced budget in each period so UI cannot be used for consumption smoothing. In their paper, there is a distinction between two sources of unemployment, stemming from matching frictions (in booms) and job rationing (in recessions). In recessions, the moral hazard problem is smaller than in booms because of the limited number of jobs available, while the value of consumption smoothing remains constant over the cycle. Due to job rationing the individual effort to find a job creates a negative externality to other job seekers. In this setting, the optimal UI rule implies more generous benefits in recessions than in expansions, which correct the negative externality by reducing job search effort. Mitman and Rabinovich (2011) also study the optimal provision of UI over the business cycle using a general equilibrium search model in which they allow for aggregate productivity shocks. They also consider the optimal design of both the level and duration of benefits. They find that the optimal path of benefits is pro-cyclical. The main difference with the previous studies is that they allow for wage bargaining, which implies that UI benefit changes do affect wages, instead of assuming rigid wages.

\section{Other Design Issues}

Finally, as we discussed above, workers can affect their work effort and induce quits, which will affect the unemployment inflow. In order to discourage quits and shirking, the system UI should induce a large drop in consumption at beginning of the unemployment spell. A waiting period before benefits are paid out is a way to discourage quits. Another way to discourage quits is by providing benefits only to unemployed who were laid off and not to those who voluntarily quit their jobs.

Unemployed workers may look for jobs, and once employed, may quit or induce a layoff quickly in order to upgrade their benefits. To prevent such cycles of unemployment spells with short intermediate employment spells eligibility criteria are important. The optimal policy should condition the benefits paid to unemployed workers on their employment history, such that the coverage increases with the length of previous employment spells (Hopenhayn and Nicolini, 2009). As we will discuss below, in most existing UI systems eligibility criteria include a minimum employment period preceding the unemployment spell. When these criteria are not satisfied then the unemployed is either not eligible for benefits or may only receive the benefits not used in the previous unemployment spell. 


\section{$2.2 \quad$ Empirical evidence}

This section reviews the empirical evidence concerning the effect of unemployment insurance on the behavior of unemployed workers. The empirical evidence on the inflow into unemployment is rather limited. Therefore, we focus on studies on unemployment outflow and the evidence on the effect of UI on post-unemployment outcomes, in particular wages and job durations. We also review studies that challenge the moral hazard effects of UI by emphasizing the effects of liquidity constraints or advocating that UI benefits should be cyclically dependent.

\subsubsection{Unemployment outflow}

The empirical literature on how UI affects the exit rate from unemployment is very large. Reviews of the early literature are given by Atkinson and Micklewright (1991) and Pedersen and Westergard-Nielsen (1993). The early literature focused mostly on the effect of the level of benefits using cross-sectional variation at the individual level. Benefit levels are generally found to have significant effects in U.S. and U.K. studies, while most continental European studies find insignificant or weak effects. In most US studies the elasticity of unemployment duration with respect to benefit level is in the range 0.3 to 0.9 (Holmlund, 1998). The disincentive effect of benefit level on the exit rate from unemployment depends also on the spell duration, with higher effects for short-term unemployed (Nickell, 1979; Fallick, 1991). The research on the effect of potential benefit duration (PBD) on the exit rate from unemployment is extensive both in the US and in Europe. Older studies for the US and Canada include Ham and Rea (1987), Meyer (1990) and Katz and Meyer (1990). Early studies for Europe are Hunt (1995), Carling et al. (1996) and Winter-Ebmer (1998). One common finding of most studies is a sharp increase in the exit rate close to benefit expiration. ${ }^{9}$

More recently, a number of U.S. and European studies have exploited policy driven changes in benefit levels. These studies examine how UI recipients react to incentives using a quasiexperimental identification of the treatment effect that allows the researchers to adopt a differencein-difference approach. The policy change allows for a before-after comparison; the first difference. Then, there is usually a treatment group that is affected and a control group that is not affected; the second difference. The difference-in-differences gives the treatment effect of the policy change. Other recent studies use a regression discontinuity methodology exploiting one or more discontinuities in the relationship between benefit level or benefit duration as for example age at inflow or pre-unemployment work experience. The assumption is that individuals on either side of the discontinuity only differ slightly, except for the exposure to a different UI benefit level or benefit duration. The difference in behavior of individuals close to either side of the discontinuity then reveals how the difference in UI affects behavior. An overview of recent studies on the effects of UI on unemployment outflow is provided in the top part of Table 1. 
The studies are characterized in terms of country, calendar time period, sample size, treated population, the identification strategy and the effect of UI on duration using two indicators for the dose-response effects to enable a comparison between the studies.

\section{Difference-in-Difference Studies}

Card and Levine (2000) study an extension of UI benefits in the state of New Jersey in 1996. For political reasons unrelated to the state of the labor market UI benefits were temporarily for a period of 26 weeks - extended with 13 weeks. The authors compare the unemployment exit rates before, during and after the benefit extension was introduced finding a decrease of the exit rates by about $15 \%$. From simulations of the long-term effect of the benefit extension they conclude that the 13 weeks of extra benefits would raise the average duration of regular UI claims by about 1 week.

Carling et al. (2001) study the effects of a cut in Swedish replacement rates in January 1996 from a maximum of $80 \%$ to $75 \%$. Because of a ceiling on the benefit level actual replacement rates can be lower than the maximum rates while for high earnings workers the UI replacement rate is not affected at all. The authors compare the job-finding rates of UI recipients younger than 55 years who were affected by the cut in the replacement rates with the job-finding rates of workers who were not affected. They distinguish two treatment groups, one with exact $80 \%$ replacement before the change and $75 \%$ after the change and one group with a replacement rate between $75 \%$ and $80 \%$ before the change and $75 \%$ after the change. There is one control group with individuals for whom the cut in benefits did not apply because their earnings were always above the threshold. The authors find that the cut in UI benefits substantially increased the outflow from unemployment with an implied elasticity of the hazard rate with respect to benefits of about 1.6.

Roed and Zhang (2003) present an analysis of unemployment durations of Norwegian workers who were below 60 years of age, became unemployed during the 1990s and who were eligible for unemployment benefits. They exploit two particular features of the Norwegian benefit system. First, UI benefits depend on the entry month into unemployment because they are calculated on the basis of earnings during the previous calendar year. Second, benefits are indexed depending on the entry month. Furthermore, because of the ceiling in earnings the replacement rate goes down with earnings for workers who earned more than the ceiling. These are sources of independent variation in replacement rates the authors use to estimate benefit elasticities which they find to range from 0.95 for men to 0.35 for women. This implies that a $10 \%$ reduction in benefits may cut a 10-month unemployment duration by approximately one month for men and 1-2 weeks for women.

Van Ours and Vodopivec (2006) exploit a policy change in Slovenia that involved substantial reductions in the potential duration of UI benefits for four groups of workers plus no change in 
benefits for another group, which served as a natural control. The distinction between the four groups is on the pre-unemployment work experience. Depending on this experience the PBD could be reduced from 6 to 3,9 to 6,12 to 6 or 18 to 9 months. The effect of the reduction in maximum benefit duration on the unemployment duration depends on the size of the reduction but also on the age and gender of the worker. Based on the parameter estimates of their hazard rate models they perform simulation from which it appears that for a 30-old male worker in good health for whom the PBD was reduced from 12 to 6 months the median unemployment duration reduced with 1.1 months; for a female worker with the same characteristics the drop in median unemployment duration was 3.5 months.

Lalive et al. (2006) study a policy change in the structure of the UI benefits in Austria which affected various unemployed workers differently. A first group experienced an increase in the replacement rate, a second group experienced an extension of the PBD, a third group experienced both a higher RR and a longer $\mathrm{PBD}$, and a fourth group experienced no change in the policy parameters. What happened to an individual depended on the monthly income of the worker and the work experience and age of the worker. For workers with high previous work experience PBD increased, respectively, from 30 to 39 weeks for the age group 40-49, and from 30 to 52 weeks for workers 50 and older. The sample consists of UI recipients in the age range 35 to 54 . The authors estimate hazard rate models and on the basis of their parameter estimates they present simulation results. An increase in PBD from 30 to 39 weeks leads to an increase of 0.4 week of unemployment while an increase in PBD from 30 to 52 weeks increase the unemployment duration with 2.3 weeks. The increase in the RR of $4.6 \%$-point leads to an increase in the unemployment duration of 0.4 weeks, implying a benefit elasticity of approximately 0.4 .

\section{Regression Discontinuity Studies}

Card et al. (2007b) exploit a discontinuity in the relationship between work experience and UI entitlement for Austrian workers. Individuals with less than 36 months of employment in the past five years receive 20 weeks of benefits, while those who have worked for 36 months or more receive 30 weeks of benefits. Using a sample of workers aged 20-50 the authors find that UI recipients who are eligible for 30 weeks of benefits exhibit job finding rates during the first 20 weeks who are 5-9\% lower than those who are eligible for only 20 weeks of benefits.

Lalive (2008) exploits an age-specific change in the maximum benefit duration in Austria in June 1988; for workers age 50 or more the PBD was extended from 30 weeks to 209 weeks in some regions but not in others. He uses this age discontinuity in UI entitlement to establish the effect of the PBD extension on the unemployment duration. The data refer to workers aged 46 to 53. From the estimates it appears that for men the duration of job search is prolonged by about 14.8 weeks, while for women this increase is 74.8 weeks. This difference is attributed 
to the age distance to early retirement age. The early retirement age for women is 54 while for men it is 59. Apparently, for older Austrian women UI provided a quantitatively important pathway into early retirement.

In January 2003 unemployment benefits in Finland were increased for workers with long employment histories. The average benefit increase was $15 \%$ for the first 150 days of the unemployment spell. At the same time the severance pay system was abolished. ${ }^{10}$ Uusitalo and Verho (2010) using this policy change to analyze the effect of the UI replacement rate on unemployment duration find that the change in the benefit structure reduced the re-employment hazards on average by $17 \%$. The effect is largest at the beginning of the unemployment spell and disappears after the eligibility for the increased benefits expires. Based on their estimates the authors conclude that the benefit increase extended time until re-employment by 33 days or $11.9 \%$. Given that the benefit increase was $15 \%$ this implies that the elasticity of time until re-employment with respect to the replacement rate would be about 0.8 .

Finally, Schmieder et al. (2012a) implement a regression discontinuity design using German data of workers in the age range 40 to 49 entering unemployment between July 1987 and March 1999 when the UI system was stable. In this age range over the particular period of time there were three sharp age thresholds in the potential benefit duration: age 42 (12 to 18 months), age 44 (18 to 22 months), and age 49 (22 to 26 months). The authors find that for each additional month of UI durations the unemployment duration increases on average with $0.10-0.13$ months. $^{11}$

\section{Discussion}

The main conclusion that can be drawn on the basis of the overview of studies presented in Table 1 is that there are substantial effects on unemployment duration if the replacement rate or the potential benefit duration change. The magnitude of the effects differs for different countries and different types of policy changes, but the effects are not so much different. An extension of potential benefit duration leads to an increase in actual unemployment duration of about $20 \%$ of the original benefit duration extension. One of the exceptions is for Slovenian women, the other is for Austrian women. The first may have to do with the attachment to the labor market, the second with the nearness of early retirement benefits. The benefit elasticity seems to range between 0.4 and 1, with the Swedish findings of Carling et al. (2006) as an exception. Although the ages of the workers being investigated differs, age differences between treatment effects seem rather limited, with the exception of Austrian older women. Incentives clearly matter. The job finding behavior of unemployed workers is influenced both by the level and the duration of the UI benefits.

An important dimension in the optimal design of UI is to understand if any of the two main components of the benefit system - benefit level and benefit duration - matter more by 
affecting differently the behavior of unemployed workers. The existing evidence suggests that both types of increase in the generosity of the UI system lead to longer unemployment duration. Consistent with the theory, most of the effect of the increase in benefit levels takes place early in the unemployment spell, while in the case of the extension of benefit duration most of the effect arises around the dates when benefits expired. An intuitive way to compare PBD and $\mathrm{RR}$ is by splitting up the total increase in benefit costs into the fraction of direct costs (without behavioral changes) and the fraction of indirect costs resulting from changes in behavior. For example, an increase in $\mathrm{RR}$ will raise benefit payments even if individuals do not change their behavior, simply because higher benefits have to be paid for the same number of days individuals spend in unemployment. Furthermore, the RR increase will induce individuals to stay longer in unemployment, thus raising benefit payments further. Lalive et al. (2006) who perform such an exercise find that an increase in PBD induces a substantially higher share of behavioral costs than an increase in RR. In other words, individuals react strongly to the increase in benefit duration, and these behavioral changes are the main factor driving the total additional costs of the policy change. Differences in replacement ratios are here of lesser importance.

The finding that changes in the duration of benefits leads to stronger effects compared to changes in the level of benefits means that benefit duration is a more effective tool to influence incentives. One concern is that the quality of post-unemployment jobs is affected too. The higher exit rate from unemployment might be associated with jobs of lower quality and with higher probability of re-entering unemployment. We discuss the empirical findings of the relationship between PBD and the quality of post-unemployment jobs in the next section.

\subsubsection{Post-unemployment outcomes}

Unlike the evidence for the effect of UI and in particular of benefit duration on the outflow rate, the evidence on the effect on post-unemployment outcomes is mixed. In older studies the main conclusion regarding the effect of UI on wages suggests a weak positive effect. There is, however, variation in the evidence with some studies finding no effect while others finding positive effects. ${ }^{12}$

Early $20^{\text {th }}$ century studies include Addison and Blackburn (2000) who find that more generous UI either in terms of the benefit level or longer entitlement periods hardly increase reemployment wages. The evidence on the effect of the UI system on employment duration is rather mixed. Evidence from Canada (Belzil, 2001) and the US (Centeno, 2004) suggests that jobs accepted close to benefit termination have a higher dissolution rate while higher benefit levels increase the quality of job match measured by the duration of the employment spell. ${ }^{13}$ An overview of recent studies on the effects of UI on post-unemployment outcomes using a dif-in-dif or regression discontinuity approach is provided in the bottom part of Table 1.

The study by Card et al. (2007b), which was discussed before, shows that extended benefits 
do not affect the "match quality" of subsequent jobs as measured by mean wages or the duration of subsequent jobs. Centeno and Novo (2007) exploit an age-specific change in entitlement introduced in Portugal in July 1999. For the age group 30 to 34 the maximum benefit duration was increased from 15 to 18 months, for the age group 35 to 39 it stayed 18 months. The new law appears to have had a small positive impact on reemployment wages; the 3 months benefit extension increased the wages with 2.8 percent. The increase was somewhat stronger at the bottom of the reemployment distribution. Van Ours and Vodopivec (2008) use the policy change in Slovenia which reduced the PBD for many groups of workers substantially to investigate the quality of post-unemployment jobs. They find that the reduction in the potential benefit duration did not affect the likelihood of a worker taking a temporary rather rather than a permanent job, had hardly any effect on job separation rates and did not affect post-unemployment wages.

Finally, Caliendo et al. (2012) focus on a discontinuity in the German UI system where at the age of 45 the maximum benefit duration increases by 6 months from 12 to 18 months. They investigate an inflow sample into unemployment for West-Germany from the years 2001 to 2003. Men are ranged between 44 and 46 years, women between 43.5 and 46.5 years. The authors find that the exit rate from unemployment decreases because of the extended benefit period (with $14 \%)$. The overall effect of the extended benefit duration on the exit rate from subsequent employment is negative but small and not significantly different from zero. However, the treatment effect is heterogeneous. The same applies to the post-unemployment wages. Unemployed who obtain jobs close and after the time when benefits are exhausted are significantly more likely to exit subsequent employment and receive lower wages compared to their counterparts with extended benefit duration.

Whereas in every study there is evidence of replacement rate or potential benefit duration to affect the job finding rate, the evidence on post-unemployment outcomes suggests that there are no effects on average on the quality of the post-unemployment job. However, there is some evidence that there are heterogeneous effects, which lead to zero net effects when this heterogeneity is ignored, indicating that at least some individuals might be liquidity constrained. Given this mixed evidence, it is difficult to provide a clear interpretation of these findings and their implication for the wage-setting process. The lack of evidence of post-unemployment effects may indicate that there is no UI-induced wage bargaining, as one would expect to observe an effect on re-employment wages. However, it may also be the case that wages are an imperfect indicator of the job characteristics that workers value.

\subsubsection{Recent debate}

The conventional disincentive or moral hazard effect of UI has been challenged recently in two directions: liquidity constraint and cyclical dependency of UI benefits. 


\section{Liquidity constraint and moral hazard}

Workers remain longer unemployed when they receive more generous benefits. This may be due to a moral hazard effect. An alternative explanation is that this is due to liquidity constraints. Chetty (2008) uses variation in severance pay policies across firms in the U.S. to identify the effect of liquidity constraints. A severance payment is a lump-sum payment that does not influence the leisure-work tradeoff and therefore should not have an effect on behavior unless through a liquidity constraint. Chetty's analysis is based on 2441 individuals of whom $471(18 \%)$ report receiving a severance payment. There is no information about the size of the severance payments. From his analysis Chetty concludes that 60 percent of the increase in unemployment durations caused by UI benefits is due to a "liquidity effect" rather than distortions in marginal incentives to search - the moral hazard effect. Chetty finds two pieces of evidence. First, increases in benefits have much larger effects on durations for liquidity constraint households. Second, lump-sum severance payments increase durations substantially among constrained households.

The change in the Finish UI system exploited by Uusitalo and Verho (2010) to investigate the effect of RR on unemployment durations was not one to one. The eligibility criteria for the severance pay in the old system were slightly different than the eligibility criteria of higher daily allowance in the new system, and there were small groups of unemployed who lost the right to the severance pay without becoming eligible for the higher daily allowance (1420 individuals) or who gained higher allowance though they were not eligible for the severance pay before the reform (681 individuals). These small groups were used to disentangle the effect of the removal of severance pay and the effect of the higher RR in the early period of unemployment. The authors find that the effect of the lost severance pay is insignificantly different from zero.

Whereas both Chetty (2008) and Uusitalo and Verho (2010) only have a relatively small number of observations, Card et al. (2007b) have many more observations to estimate the effects of severance pay (see also Table 1). They compare the search behavior or people who were laid off just before and just after the 36-month cutoff for severance pay eligibility. They find that the lump sum severance pay has a significant effect on the duration of joblessness. The job finding rate during the first 20 weeks of unemployment (the eligibility period for regular unemployment benefits in Austria) is 8-12\% lower for those who are just barely eligible for severance pay than for those who are just barely ineligible. A substantial share of the behavioral response to longer UI benefits is attributable to a liquidity effect rather than due to moral hazard. All in all, the importance of liquidity constraints is still not well established.

\section{Cyclical variations in UI benefit generosity}

The disincentive effect of UI may be sensitive to the business cycle and lower during recessions because of higher search costs and weaker labor demand. The occurrence of longer unemploy- 
ment duration during recessions may call for more generous benefits since the trade-off between consumption smoothing and moral hazard is different than in a booming labor market with low unemployment.

There are few countries in which the UI structure depends on the business cycle conditions and in particular on the regional unemployment rate (Canada, Poland and the U.S.). In the case of the U.S., there is an extension of up to 20 weeks through the Extended Benefits program to the regular benefit duration of 26 weeks. This extension is provided to those unemployed who lost their job in states in which the level and the change in the state unemployment rate exceeds a certain threshold. Although the thresholds vary across states, the typical lower threshold is 6.5 percent for extensions of 13 weeks and 8.0 percent for extensions of 20 weeks. These are combined with an increase of 10 percent in the unemployment rate over the previous two years. This system has been present for decades (Kiley, 2003). As a response to the Great Recession of 2008/2009 there were four additional extensions of unemployment benefit duration on top of the automatic extension of 20 weeks. Maximum UI durations in the U.S. were extended to as long as 99 weeks. ${ }^{14}$ The U.S. system of cyclical variation in UI benefit generosity is relatively unusual for other OECD countries.

There is some recent empirical evidence in support of cyclical variations in UI benefit generosity. Kroft and Notowidigdo (2010) show for the U.S. that the elasticity of unemployment duration with respect to the UI benefit level varies with the unemployment rate. Theoretically, the duration elasticity depends on the relative importance of search effort and reservation wage. Through the reservation wage, there is a positive correlation between the duration elasticity and the unemployment rate, while through search effort there may be a negative correlation. Empirically there is a negative correlation between the duration elasticity and the unemployment rate. This implies that moral hazard is lower when unemployment is high. Schmieder et al. (2012a) find similar results for Germany. These findings suggest that extensions of UI duration during recessions can be welfare enhancing.

\section{Labor market performance and UI systems}

\subsection{Labor market performance}

Table 2 presents differences in labor market position for prime age -25 to 54 - and older -55 to 64 - individuals distinguished by gender. In 2010 unemployment rates for prime age men ranged from a low 3.0\% in Luxembourg to a high $18.1 \%$ in Spain. For prime age women the ranges in unemployment rates are similar, from a low $2.6 \%$ in Norway to $19.2 \%$ in Spain. For prime age men the range in employment rates is limited from a low $75.4 \%$ in Estonia to a high $92.4 \%$ in Switzerland. For prime age women the range of the employment rates is substantially larger, from 30.1 in Turkey to $82.2 \%$ in Norway. 
Unemployment rates are very much the same for older and prime age individuals. The fact that unemployment rates among older workers are rather low does not necessarily mean that the UI system has no influence. Usually older employed workers have a low probability to lose their job so the fact that they have an average unemployment rate may point to unemployment duration being above average.

Among older men and women employment rates are substantially lower than among prime age individuals. The employment rate among older males in Hungary is at the low end with $39.6 \%$ and in Iceland it is at the high end of the distribution with $83.9 \%$. Among older females employment rates are even lower with Turkey having the lowest with $17.1 \%$ and Iceland being the highest with $77.0 \%$.

Table 2 also presents cross-country information on the percentages of long-term unemployment in overall unemployment, that is the share of unemployed with an unemployment duration of more than 1 year. Whereas the cross-country variation in unemployment rates was rather limited, the variation in the share of long-term unemployed is substantial. Korea has the shortest unemployment durations with only $1 \%$ of male unemployment and $0 \%$ of female unemployment lasting longer than one year. At the top end of the unemployment durations is the Slovak Republic with a long-term unemployment share for males of $58 \%$ and for females of $61 \%$.

\subsection{UI systems}

From the overview of empirical studies it is clear that the differences in magnitude of the effects of replacement rate and benefit duration on unemployment duration are not so big despite differences in research design and sample. In this section we discuss cross-country differences in UI systems to illustrate that this similarity in findings is all the more remarkable since the structure of UI systems differ between countries in a number of dimensions although there are similarities. One of the similarities between the various systems is related to the eligibility conditions. These conditions include the requirement to be involuntary unemployed, being registered in the employment office and actively seeking for employment. ${ }^{15}$ Another similarity is the existence of a qualifying period for eligibility. The requirement is a minimum number of weeks, months or days of employment during a specified period before entering unemployment. In few countries there is a separate employment and contributions requirement. As shown in the first column of Table 3, the exact requirements vary a lot across countries; about 6 months of employment and contributions in the last one or one-and-a-half year in Austria, Japan, Korea, Luxembourg and Sweden; 1 year in the last 2 years in Germany, Italy, Portugal and Switzerland; 4 months in the last 2.3 years in France; 1 year in the last 3 years in Denmark and Estonia; 1 year in the last 4 years in Hungary; 1 year in the last 6 years in Spain. In the U.S., few states require a specified number of weeks (15 or 20), while most states require minimum earnings which equal to a specified multiple of the weekly benefit amount. 
A waiting period of few days for the eligible unemployed exists in a number of countries: 14 days in Canada and up to 14 days in New Zealand, 7 in Estonia, Finland, France, Italy, Japan, Korea and U.S.; 6 in Greece; 5 in Sweden and Switzerland and 3 in Ireland, Norway and the U.K.

In most countries benefits are determined by the previous earnings of the unemployed. The earnings base is usually the average of a specified period before becoming unemployed (gross or net), which varies from 1 month (Belgium) to 3 months (Czech Republic, Denmark, Italy, Korea, Luxembourg), 6 months (Canada, Iceland, Spain) or 1 year (Estonia, France, Hungary, Netherlands, Portugal, Slovenia). Few countries consider a reference earnings level instead of the individual earnings as the base for calculating the amount of benefits. This reference level is the national minimum wage for Greece or the state weekly average earnings in the U.S. A flat benefit exists in Australia, Greece, Ireland, New Zealand, Poland and the U.K., while most other countries impose a ceiling on the benefit amount. The payment rate, which is a percentage of the previous earnings, varies from 50 per cent (Estonia, Korea, Slovak Republic, Turkey, United States), to 90 per cent in Denmark. Many countries have a declining profile of the payment rate over the duration of unemployment. Such declining benefits are present in Belgium, Czech Republic, Estonia, Hungary, Italy, the Netherlands, Poland, Slovenia, Spain, Sweden, Switzerland and Turkey.

The maximum benefit duration is either fixed or depends on the insurance period and/or age. Only few countries set a fixed maximum benefit period, which is 24 months in Denmark (since 2012 while it used to be 48 months before), 500 days in Finland, 6 months in Slovak Republic, and 26 weeks in the U.K. and the U.S. In mostly all other countries the maximum benefit duration varies both within and between countries. The within variation depends on the contribution history and in some countries also on age (Austria, France, Germany, Greece, Italy, Korea, Luxembourg, Japan, Portugal, Switzerland). The age dimension in most of these countries is related to older workers, for which the duration of benefits is usually longer. Only Germany and Portugal have a structure of benefit duration which depends on both the history of contributions and age for also younger workers. The variation of the minimum benefit duration between countries ranges from a around 3 months in Canada, Japan, Korea, Slovenia and Turkey, around 6 months in Estonia, Greece, Germany, Italy, Poland, 1 year in Norway and Sweden and 2 years in Portugal. The maximum benefit duration varies from 5 months in Czech Republic, 8 months in Korea, 9 months in Hungary, 10 months in Canada, 1 year in Austria, Estonia, Greece, Ireland, Italy, Slovenia, Turkey, 2 years in Germany, Norway, Spain and 72 months in Portugal. In Australia, Belgium and New Zealand there is an unlimited duration, while in three countries (Canada, Poland and the U.S.) the duration of benefits depends also on the regional (state) unemployment rate. 


\section{Policy issues concerning the design of UI systems}

In this section we draw conclusions about relevant policy issues related to the design of the UI system. We confront the main lessons from the literature overview on UI related incentives with the characteristics of the UI systems across countries.

\subsection{Benefit structure}

In most countries the maximum benefit duration is age-dependent, either directly (especially in Europe) or through entitlement criteria that relate the maximum duration of benefits to previous work experience. The rationale behind age-dependent unemployment insurance is twofold. The first is related to the labor market position of older workers who once unemployed might face worse employment prospects. The second is related to the fact that young and older workers are characterized by different expected horizons in the labor market.

To the extent that the labor market position of older workers is weak the insurance component in the trade-off between providing insurance and reducing moral hazard is larger. However, unconditional extension of benefits to older workers might reduce their re-employment incentives. Recent evidence suggests that, in countries in which UI can be used as a pathway to early retirement, unemployment for older workers is an absorbing state (Tatsiramos, 2010).

The proximity to retirement might also modify the trade-off between insurance and incentives. For instance, a declining profile of benefits that we observe in a number of countries might not be effective in introducing incentives to exit from unemployment when there is short distance to retirement. As discussed in Section 2.1.4, the theory of optimal UI suggests that employment taxes can be combined with a declining profile of benefits in order to create incentives for exiting unemployment. For older workers incentives to search and find a job may be increased by providing employment subsidies. However, if the time horizon is too short this will not work either. Shortly before retirement - up to a couple of years - older unemployed workers may stop searching for a job altogether irrespective of the structure of benefits and taxes or subsidies on employment. Combining the UI system and pension system may revitalize search of older unemployed workers, for example by taxing pensions in proportion to the length of the unemployment spells (Hairault et al., 2010). Providing age-dependent benefits in the form of longer benefit durations for older workers in combination with a tax on pensions will provide more insurance and at the same time introduce incentives to search for employment.

\subsection{Eligibility conditions}

Eligibility conditions include general conditions of being available for work and actively searching for a job, the qualifying period that is required to be employed in order to be eligible for benefits, the waiting period that is required before the benefits are available for the unemployed and the 
condition to be laid off. These conditions are in general in line in all countries with the optimal design of a UI system (Hopenhayn and Nicolini, 2009), which we discussed in Section 2.1.4. Linking eligibility to benefits with the employment history is certainly an effective mechanism to prevent unemployment cycles with short intermediate employment spells.

The eligibility conditions may be also used to enhance the incentives to search for employment throughout the unemployment spell and reduce the tendency of some unemployed to search more intensively only closer to when benefits are about to expire. Given that jobs found closer to benefit exhaustion can be of lower quality (e.g. Belzil 2001; Centeno 2004; Caliendo et al. 2012) creating incentives to find jobs faster can have important welfare effects. One possible way to achieve this is to link directly the qualifying period with the duration of the unemployment spell by considering a qualifying period which is increasing with the unemployment duration. Contrary to the eligibility condition of a qualifying period (minimum employment period) that affects the incentives during employment, linking the qualifying period with the length of the unemployment duration could introduce additional incentives during the unemployment spell. These additional incentives might reduce the spike in the exit rate from unemployment closer to when benefits are about to expire by defining another focal point earlier in the unemployment spell, i.e. the unemployment duration with the minimum employment duration required to become eligible for unemployment benefits in a future unemployment spell.

\subsection{Business Cycle}

There are two ways business cycles affect unemployment. The first, which is a direct one, is related to an increase in layoffs and reduction of hirings by firms in the case of a recession. The second, which is indirect, is related to a change in the composition of unemployed workers. For instance, during a recession more older workers and higher educated ones enter the unemployment pool. To the extent that the direct effect of the recession on the unemployment rate and the compositional change are large, there is scope for labor market policies to adjust. ${ }^{16}$

The occurrence of longer unemployment duration during recessions may call for more generous benefits since the trade-off between consumption smoothing and moral hazard may be different than in a booming labor market with low unemployment. In particular, with a weaker labor demand during a recession, unemployed workers may face difficulties to find a new job, which increases the consumption smoothing purpose of UI. On the other hand, cyclical adjustment of maximum benefit duration might also affect incentives for UI recipients reinforcing moral hazard problems. These disincentives may be more pronounced for low income workers because the gains from working decline with benefits generosity. However, these workers might be more liquidity constrained (Browning and Crossley, 2001) and benefit more from more generous UI through consumption smoothing. The evidence presented in Section 2.2.3 shows that the disincentive effect of benefit extensions in the recent recession has contributed to a small 
extent to the the increase of unemployment and that extensions of UI duration during recessions can be welfare enhancing.

\section{Concluding remarks}

UI provides unemployed workers with benefits in order to smooth consumption. UI also creates disincentives for employed workers to retain their jobs and unemployed workers to find new jobs. The design of UI needs to consider the trade-off between insurance and incentives. Benefit structure and eligibility conditions are the most important elements for the design of UI. The benefit structure determines the replacement rate and the duration of benefit receipt, which shape the incentives to search for a job and, therefore, the unemployment outflow. The eligibility conditions, which affect the unemployment inflow, specify the requirements in order to be eligible for UI. These include general conditions of being available for work and actively searching for a job, the qualifying period that is required to be employed in order to be eligible for benefits, the waiting period that is required before the benefits are available for the unemployed and the condition to be laid off.

There is a lot of cross-country and within-country variation in the structure of UI systems. The cross-country differences are hard to exploit in empirical studies because there are many other differences between countries that influence labor market behavior. The within-country variation in UI because of discontinuities in rules or because of calender time changes in the UI structure allow researchers to establish the effects of replacement rates and maximum benefit durations on labor market outcomes. In the overview of empirical studies we find that the differences in magnitude of the effects of replacement rate and benefit duration are not so big despite differences in research design, sample and UI structure. Apparently, the behavior of unemployed workers is affected by the two main characteristics of UI systems in a similar way despite the obvious differences between these systems and other differences in labor market institutions such as employment protection legislation, minimum wages and active labor market policies.

We identify four main issues for future research on UI design: personal versus public provision, the importance of liquidity constraints, behavioral biases, and the optimality of adjustment of the UI system over the business cycle. In all these issues the common element is the extent to which moral hazard affects individual behavior and how this changes over the economic conditions and over time.

In the discussion on public versus private provision of UI there is sometimes a reference to mandatory UI savings accounts. Individual savings accounts can combine consumption smoothing in the case of job loss without introducing moral hazard effects. This is an interesting combination but as yet there is little experience with its practical operation or possible effects 
in a transition period. ${ }^{17}$

The importance of liquidity constraints is still an open issue. Yet, from a policy point of view it is very important whether the positive correlation between generosity of benefits and unemployment duration have to do with adverse effects on search behavior or with lifting liquidity constraints so that unemployed workers can find better jobs. To disentangle these two sources of prolonged unemployment duration requires a better understanding of the way unemployed search and how this changes over time. This understanding will also shed light on the existence of spikes in the job finding rates, which are associated with worse job matches.

Recently, researchers have begun to investigate to what extent behavioral biases affect job search and thus the way UI influences search behavior. UI recipients may be "impatient", i.e. they assign a lower value to future benefits of job search and therefore exert less effort to find a job. In addition to this, welfare recipients may have so-called hyperbolic time preferences, i.e. they are "present biased" in the sense that in the short run they discount highly while in the long run they discount less. Paserman (2008) introduces hyperbolic discounting in job search decisions. Della Vigna and Paserman (2005) investigate the relevance of impatience and hyperbolic discounting in job search decisions. They find that the effect of impatience on search effort is negative and sizable while the effect of impatience on reservation wages and re-employment wages is essentially zero. Clearly, the way individuals discount the future, understand the rules of the game and are influenced by the behavior of others are likely to explain the observed behavior and provide insights for policy changes that will increase welfare without reducing efficiency. Alternatively, different type of data may be used to investigate the effects of UI on behavior. Krueger and Mueller (2010) for example exploit time-use data to investigate behavioral response to UI finding evidence of liquidity-constraints to have an impact on job seekers.

Finally, according to the OECD (2011) the Great Recession served as a tough "stress test" to the social safety-nets in OECD countries. Many OECD countries took crisis-related measures to reinforce the insurance part mainly by expanding benefit coverage to previously ineligible groups of workers. The OECD (2011) concludes that overall benefit generosity has hardly increased so the expanding of the coverage was not at the expense of a reduction in incentives to find a job. Whether a UI system is generous not only depends on the level and maximum duration of the UI benefits but also on the duration of unemployment. If the actual duration of unemployment is short it is not very important if the maximum benefit duration is short too. If the maximum benefit duration is long but the actual unemployment duration is even longer benefits are not very generous. A further complication is that both durations are not independent. A long maximum duration may cause a long actual duration of unemployment.

Recent theoretical studies show that the optimal UI depends on the state of the labor market such that in recessions more generous benefits may be provided. In addition, to the extent to 
which individual heterogeneity and duration dependence varies over the business cycle, UI that varies with business-cycle dependent UI might be relevant. During a recession more generous benefits can be provided since the trade-off between consumption smoothing and moral hazard is different than in a labor market with high unemployment. Whether the cyclical sensitivity of optimal UI implies that a UI system should have automatic adjustments in terms of generosity is another matter. This also depends on the costs of such automatic adjustments in terms of behavioral responses. If unemployed workers anticipate a recession they may try to postpone becoming unemployed until the economy is in a recession. Once in a recession the lower search effort might prolong the recession. In other words, the magnitude and duration of a recession may not be exogenous to labor market behavior of unemployed workers.

A major characteristic of UI systems is that they are constantly changing. Apparently it is difficult to implement the optimal design. To some extent these changes have to do with changes in the economy and changing political preferences. They are also a matter of trial and error, which results from limited understanding of the individual behavioral responses to the introduction of new policies. The effectiveness of new features of a system and new policies depends on the way individuals react to these changes. It is only after evaluating these policies that we can learn about their effectiveness, although in many cases it is still not clear why some policies work and some other do not. Optimal UI design can only be implemented if the behavior of unemployed and employer workers is better understood.

\section{Acknowledgment}

The authors would like to thank two anonymous referees for helpful comments on a previous version of the paper. 


\section{Notes}

${ }^{1}$ Previous overview studies are at least a decade old; see Atkinson and Micklewright (1991), Holmlund (1998), Karni (1999) and Krueger and Meyer (2002). To some extent Fredriksson and Holmlund (2006a and 2006b) also provide an overview but their study is much more limited in scope when it comes to UI benefits and much wider since they also discuss benefit sanctions and workfare policies.

${ }^{2}$ See Arpaia and Mourre (2012) for a recent discussion on labor market institutions and performance of European labor markets.

${ }^{3}$ Dolls et al. (2012) find that in the presence of an unemployment shock the benefit system absorbs 48 percent of the shock in the EU, compared to 34 percent in the U.S.

${ }^{4}$ Van der Klaauw and Van Ours (2012) provide an overview over studies on the effectiveness of benefit sanctions and reemployment bonuses. Kluve (2010) presents a meta-analysis of 137 ALMP evaluation studies in Europe finding that simple non-expensive programs with clear incentives for unemployed workers work best. Card et al. (2010) also present a meta-analysis of ALMP evaluations with similar findings but emphasizing that longer-term evaluations generally tend to be more favorable than short-term evaluations.

${ }^{5}$ See the Appendix for a short technical presentation on unemployment benefits in a job search model and an equilibrium search model. Rogerson et al. (2005) provide a comprehensive review of search models.

${ }^{6}$ We return to this issue when we discuss the optimal design of UI in section 2.1.4 and when we discuss the recent empirical evidence in section 2.2

${ }^{7}$ See Rogerson and Shimer (2011) for a review of equilibrium search models with an emphasis on business cycle fluctuations.

${ }^{8}$ Of course, if there is a direct relationship between shirking and dismissal the dismissed worker will not be entitled to UI benefits, but in practice it may be difficult to establish such a direct relationship. A mechanism to reduce the incentive for workers to quit their job in the presence of unemployment benefits is the imposition of a tax upon entering unemployment. This tax is typically in the form of a waiting period during which workers do not receive benefits. Additionally, the eligibility criteria for receiving benefits may be used to control the inflow into unemployment. Specifying a minimum employment period to contribute to the unemployment insurance fund is a way to avoid repeated cycles of short employment followed by receipt of unemployment benefits.

${ }^{9}$ Card et al. (2007a) find that close to benefit expiration the unemployment exit rate increases much more than the re-employment hazard rate does. From this they conclude that the spike in unemployment-exit rates is to a large extent due to measurement error when using data on UI benefits only. However, Katz and Meyer (1990) show that for UI recipients in the week of benefit expiration the job finding rate is about $80 \%$ higher than before, while such spikes are not present for UI non-recipients. Furthermore, using administrative data, Roed and Zhang (2003) for Norway, Lalive et al. (2006) for Austria, Van Ours and Vodopivec (2006) for Slovenia and Caliendo et al. (2012) for Germany also find evidence for the presence of end-of-benefit spikes. Clearly, the end-of-benefit spike cannot simply be discarded as a statistical artifact. Boone and Van Ours (2012) suggest that end-of-benefit spikes in job finding rates are related to optimizing behavior of unemployed workers who rationally assume that employers will accept delays in the 
starting date of a new job, especially if these jobs are permanent. This gives some workers an incentive to not immediately start working after they have found a job. Instead they wait until their benefits expire.

${ }^{10}$ The increase in benefits was calculated so that in absence of behavioral effects the expected direct cost for the UI funds would be unchanged.

${ }^{11}$ In Schmieder et al. (2012b), the authors replicate their results using only the threshold at age 42 , finding a marginal effect of 0.20 , which goes down to 0.15 if nonemployment over 5 years - after the start of the initial spell - is taken into account.

${ }^{12}$ See Ehrenberg and Oaxaca, 1976; Burgess and Kingston, 1976; Hoelen, 1977; Blau and Robins, 1986. Classen (1977) finds no relationship between the level of UI benefits and reemployment wages.

${ }^{13}$ Tatsiramos (2009) uses ECHP data to investigate the effect of UI on unemployment duration and subsequent employment stability for eight European countries. He finds that benefit recipients experience longer unemployment spells but UI also has a positive effect on subsequent employment stability. The effect of UI on employment stability is more pronounced in countries with relatively more generous UI systems such as Denmark, Germany, France and Spain when compared to countries such as Greece and Italy in which the UI system is underdeveloped.

${ }^{14}$ Rothstein (2011) concludes on the basis of an analysis of data from the Current Population Survey that the effects on unemployment exits of the benefit extensions has been rather limited. He attributes 0.1 to 0.5 percentage point of the unemployment rate to the long maximum benefit durations.

${ }^{15}$ In some countries voluntarily unemployed or those who are laid off for cause are eligible to UI although there is typically a waiting period of several weeks.

${ }^{16}$ Most of the existing empirical evidence, however, suggests that the compositional changes are rather limited. See for example Imbens and Lynch (2006), Abbring, Van den Berg and Van Ours (2001), Van den Berg and Van der Klaauw (2001) who find a small compositional effect. Mueller (2011), however, documents that in recessions the pool of unemployed shifts towards workers with high wages in their previous job.

${ }^{17}$ In a couple of Latin-American countries UI savings accounts have been introduced. A rare example of an empirical study investigating the labor market effects of these accounts is Reyes et al. (2011). 


\section{References}

[1] Abbring, J.H., Van den Berg, G.J. and Van Ours, J.C. (2001) Business cycles and compositional variation in U.S. unemployment, Journal of Business and Economic Statistics 19: 436-448.

[2] Acemoglu, D. and Shimer, R. (1999) Efficient unemployment insurance, Journal of Political Economy 107: 893-928.

[3] Addison, J.T. and Blackburn, M.L. (2000) The effects of unemployment insurance on postunemployment earnings, Labour Economics 7: 21-53.

[4] Andersen, T.M. and Svarer, M. (2010) State dependent unemployment benefits, Journal of Risk and Insurance 78: 325-344.

[5] Arpaia, A. and Mourre, G. (2012) Institutions and performance in European labor markets: taking a fresh look at the evidence, Journal of Economic Surveys 26: 1-41.

[6] Atkinson, A.B. and Micklewright, J. (1991) Unemployment compensation and labor market transitions: a critical review, Journal of Economic Literature 29: 1679-1727.

[7] Belzil, C. (2001) Unemployment insurance and subsequent job duration: job matching versus unobserved heterogeneity, Journal of Applied Econometrics 16: 619-636.

[8] Blau, D.M. and Robins, P.K. (1986) Job search, wage offers, and unemployment insurance, Journal of Public Economics 29: 173-197.

[9] Boone, J. and Van Ours, J.C. (2012) Why is there a spike in the job finding rate at benefit exhaustion? De Economist, forthcoming.

[10] Browning, M. and Crossley, T.F. (2001) Unemployment insurance benefit levels and consumption changes, Journal of Public Economics 80: 1-23.

[11] Burgess, P.L. and Kingston, J.L. (1976) The impact of unemployment insurance benefits on reemployment success, Industrial and Labor Relations Review 30: 25-31.

[12] Cahuc, P. and Lehmann, E. (2000) Should unemployment benefits decrease with the unemployment spell? Journal of Public Economics 77: 135-153.

[13] Cahuc, P. and Zylberberg, A. (2004) Labor Economics, MIT Press.

[14] Caliendo M., Tatsiramos, K. and Uhlendorff, A. (2012) Benefits duration, unemployment duration and job match quality: A regression discontinuity approach, Journal of Applied Econometrics, forthcoming.

[15] Card, D., Chetty, R. and Weber, A. (2007a) The spike at benefit exhaustion: Leaving the unemployment system or starting a new job?, American Economic Review 97: 113-118.

[16] Card, D., Chetty, R. and Weber, A. (2007b) Cash-on-hand and competing models of intertemporal behavior: new evidence from the labor market, Quarterly Journal of Economics 122: 1511-1560.

[17] Card, D., Kluve, J. and Weber, A. (2010) Active labor market policy evaluations: a meta- analysis, Economic Journal 129: F452-F477.

[18] Card, D. and Levine, P.B. (2000) Extended benefits and the duration of UI spells: Evidence from the New Jersey Extended Benefit Program, Journal of Public Economics 78: 107-138.

[19] Carling, K., Holmlund, B. and Vejsiu, A. (2001) Do benefit cuts boost job findings? Swedish evidence from the 1990s, Economic Journal 111: 766-790.

[20] Carling, K., Edin, P., Harkman, A. and Holmlund, B. (1996) Unemployment duration, unemployment benefits, and labor market programs in Sweden, Journal of Public Economics 59: 313-334.

[21] Centeno, M. (2004) The match quality gains from unemployment insurance, Journal of Human Resources 34: 839-863.

[22] Centeno, M., and Novo, A. (2009) Unemployment insurance generosity and post-unemployment wages: Quantile treatment effects, mimeo. 
[23] Chetty, R. (2008) Moral hazard vs. liquidity and optimal unemployment insurance, Journal of Political Economy 116: 173-234.

[24] Classen, K. (1977) The effect of unemployment insurance on the duration of unemployment and subsequent earnings, Industrial and Labor Relations Review 30: 438-444.

[25] Della Vigna, S. and Paserman, M.D. (2005) Job Search and Impatience, Journal of Labor Economics 23: $527-588$.

[26] Dolls, M., Fuest, C. and A. Peichl, A. (2012) Automatic stabilizers and economic crisis: US vs. Europe, Journal of Public Economics 96: 279-294.

[27] Ehrenberg, R. and Oaxaca, R.L. (1976) Unemployment insurance, duration of unemployment, and subsequent wage gain, American Economic Review 66: 754-766.

[28] Fallick, B. C. (1991) Unemployment insurance and the rate of re-employment of displaced workers, Review of Economics and Statistics 2: 228-235.

[29] Fredriksson, P. and Holmlund, B. (2006a) Improving incentives in unemployment insurance: a review of recent research, Journal of Economic Surveys 20: 357-386.

[30] Fredriksson, P. and Holmlund, B. (2006b) Optimal unemployment insurance design: time limits, monitoring, or workfare? International Tax and Public Finance 13: 565-585.

[31] Gruber (1997) The consumption smoothing benefits of unemployment insurance, American Economic Review 87: 195-205.

[32] Hairault, J., Langot, F., Ménard, S. and Sopraseuth, T. (2010) Distance to retirement and older workers' employment: the case for delaying the retirement age, Journal of the European Economic Association 8: 1034-1076.

[33] Hall, R. E. (2005) Employment fluctuations with equilibrium wage stickiness, American Economic Review 95: 50-65.

[34] Ham, J.C. and Rea, S.A. (1987) Unemployment insurance and male unemployment duration in Canada, Journal of Labor Economics 5: 325-353.

[35] Hansen, G.D. and Imrohoroglu, A. (1992) The role of unemployment insurance in an economy with liquidity constraints and moral hazard, Journal of Political Economy 100: 118-142.

[36] Hoelen, A. (1977) Effects of unemployment insurance entitlement on duration and job search outcome, Industrial and Labor Relations Review 30: 45-50.

[37] Holmlund, B. (1998) Unemployment insurance in theory and practice, Scandinavian Journal of Economics 100: 113-141.

[38] Hopenhayn, H. and Nicolini, J.B. (1997) Optimal unemployment insurance, Journal of Political Economy 105: 412-438.

[39] Hopenhayn, H. and Nicolini, J.B. (2009) Optimal unemployment insurance and employment history, Review of Economic Studies 76: 1049-1070.

[40] Hunt, J. (1995) The effect of unemployment compensation on unemployment duration in Germany, Journal of Labor Economics 13: 88-120.

[41] Imbens, G. and L. Lynch (2006) Re-employment probabilities over the business cycle, Portuguese Economic Journal 5: 111-134.

[42] Karni (1999) Optimal unemployment insurance: a survey, Southern Economic Journal 66: 442-465.

[43] Katz, L. F. and Meyer, B.D. (1990) The impact of the potential duration of unemployment benefits on the duration of unemployment, Journal of Public Economics 41: 45-72.

[44] Kiley, M.T. (2003) How should unemployment benefits respond to the business cycle? Topics in Economic Analysis \&3 Policy 3: 1-30.

[45] Kluve, J. (2010) The effectiveness of European active labor market programs, Labour Economics 17: $904-918$. 
[46] Kroft, K. and Notowidigdo, M.J. (2010) Should unemployment insurance vary with the local unemployment rate? Theory and evidence, mimeo.

[47] Krueger, A.B. and Meyer, B.D. (2002) Labor supply effects of social insurance, in A.J. Auerbach and Feldstein, M. (eds.), Handbook of Public Economics, Vol 4, Amsterdam: North-Holland.

[48] Krueger, A.B. and Mueller, A. (2010) Job search and unemployment insurance: new evidence from time use data, Journal of Public Economics 94: 298-307.

[49] Lalive, R. (2008) How do extended benefits affect unemployment duration? A regression discontinuity approach, Journal of Econometrics 142: 785-806.

[50] Lalive R., Van Ours, J.C. and Zweimüller, J. (2006) How changes in financial incentives affect the duration of unemployment, Review of Economic Studies 73: 1009-1038.

[51] Landais, C., Michaillat, P. and Saez, E. (2010) Optimal unemployment insurance over the business cycle, NBER Working Paper 16526.

[52] Marimon, R. and Zilibotti, F. (1999) Unemployment vs. mismatch of talents: reconsidering unemployment benefits, Economic Journal 109: 266-291.

[53] Meyer, B. D. (1990) Unemployment insurance and unemployment spells, Econometrica 58: 757-782.

[54] Mitman K. and Rabinovich, S. (2011) Pro-cyclical unemployment benefits? Optimal policy in an equilibrium business cycle model, PIER Working Paper No. 11-010.

[55] Mortensen, D.T. (1977) Unemployment insurance and job search decisions, Industrial and Labor Relations Review 30: 505-517.

[56] Mortensen D.T. and Pissarides, C.A. (1999) New developments in models of search in the labor market, in Ashenfelter, O. and Card, D. (eds.), Handbook of Labor Economics, Amsterdam: NorthHolland.

[57] Nickell, S. J. (1979) The effect of unemployment and related benefits on the duration of unemployment, Economic Journal 353: 34-49.

[58] OECD (2010) OECD Employment Outlook 2010, Paris: OECD Publishing.

[59] OECD (2011) OECD Employment Outlook 2011, Paris: OECD Publishing.

[60] Paserman M.D. (2008) Job Search and Hyperbolic Discounting: Structural Estimation and Policy Evaluation, Economic Journal 118: 1418-1452.

[61] Pavoni N. (2007) On optimal unemployment compensation, Journal of Monetary Economics 54:, $1612-1630$

[62] Pavoni N. and Violante, G.L. (2007) Optimal welfare-to-work programs, Review of Economic Studies 74: $283-318$.

[63] Pedersen, P. and Westergård Nielsen, N. (1993) Unemployment: a review of the evidence from panel data, OECD Economic Studies 20: 65-114.

[64] Pissarides, C. A. (2000) Equilibrium Unemployment Theory, Cambridge: MIT Press.

[65] Reyes, G., Van Ours, J.C. and Vodopivec, M. (2011) Incentive effects of unemployment insurance savings accounts: evidence from Chile, Labour Economics 18: 798-809.

[66] Roed, K. and Zhang, T. (2003) Does unemployment compensation affect unemployment duration? Economic Journal 113: 190-206.

[67] Rogerson, R. and Shimer, R. (2011) Search in macroeconomic models of the labor market, in Ashenfelter, O. and Card, D. (eds.), Handbook of Labor Economics, Vol 4A, Amsterdam: NorthHolland.

[68] Rogerson, R., Shimer, R. and Wright, R. (2005) Search-theoretic models of the labor market: a survey, Journal of Economic Literature 43: 959-988.

[69] Rothstein, J. (2011) Unemployment insurance and job search in the Great Recession, Brookings Papers on Economic Activity, Fall: 143-213. 
[70] Schmieder, J.F., Von Wachter, T., Bender, S. (2012a) The effects of extended unemployment insurance over the business cycle: evidence from regression discontinuity estimates over 20 years, Quarterly Journal of Economics 127: 701-752.

[71] Schmieder, J.F., Von Wachter, T., Bender, S. (2012b) The long-term effects of UI extensions of employment, American Economic Review: Papers 8 Proceedings 102: 514-519.

[72] Shavell, S. and Weiss, L. (1979) The optimal payment on unemployment insurance benefits over time, Journal of Political Economy 87: 1347-1362.

[73] Shimer, R (2005) The cyclical behavior of equilibrium unemployment and vacancies, American Economic Review 95: 25-49.

[74] Shimer, R, and Werning, I. (2006) On the optimal timing of benefits with heterogeneous workers and human capital depreciation, unpublished manuscript.

[75] Shimer, R, and Werning, I. (2007) Reservation wages and unemployment insurance, Quarterly Journal of Economics 122: 1145-1185.

[76] Shimer R. and Werning, I. (2008) Liquidity and insurance for the unemployed, American Economic Review 98: 1922-1942.

[77] Tatsiramos, K. (2009) Unemployment insurance in Europe: Unemployment duration and subsequent employment stability, Journal of the European Economic Association 7: 1225-1260.

[78] Tatsiramos, K. (2010) Job Displacement and the transition to re-employment and early retirement for non-employed older workers, European Economic Review 54: 517-535.

[79] Uusitalo, R. and J. Verho (2010) The effect of unemployment benefits on re-employment rates: evidence from the Finnish unemployment insurance reform, Labour Economics 17: 643-654.

[80] Van den Berg, G. J. (1990) Nonstationarity in job search theory, Review of Economic Studies 57: 255-277.

[81] Van den Berg, G. J. and Van der Klaauw, B. (2001) Combining micro and macro unemployment duration data, Journal of Econometrics 102: 271-309.

[82] Van der Klaauw, B. and Van Ours, J.C. (2012) Carrot and stick: how reemployment bonuses and benefit sanctions affect exit rates from welfare, Journal of Applied Econometrics, forthcoming.

[83] Van Ours, J.C. and Vodopivec, M. (2006) How shortening the potential duration of unemployment benefits entitlement affects the duration of unemployment: Evidence from a natural experiment, Journal of Labor Economics 24: 351-378.

[84] Van Ours, J.C., and Vodopivec, M. (2008) Does reducing unemployment insurance generosity reduce job match quality?, Journal of Public Economics 92: 684-695.

[85] Wang, C. and Williamson, S. (1996) Unemployment insurance with moral hazard in a dynamic economy, Carnegie Rochester Conference Series on Public Policy 44: 1-41.

[86] Winter-Ebmer, R. (1998) Potential unemployment benefit duration and spell length: Lessons from a quasi-experiment in Austria, Oxford Bulletin of Economics and Statistics 60: 33-45. 


\section{Appendix: Unemployment benefits in Job Search and Equilib- rium Search Models}

Partial Equilibrium Model

The basic search model is central to examine the effect of unemployment benefits on the exit rate from unemployment. We start by considering the partial equilibrium model under the assumptions that all unemployed workers receive the same amount of unemployment benefits which are paid for the entire duration of unemployment. Workers have their (dynamic) reservation wage as the only instrument of search to influence their unemployment duration. In a stationary environment, the flow value of having a job is equal to:

$$
\rho V_{e}=w+\delta\left(V_{u}-V_{e}\right)
$$

where $\rho$ is the discount rate, $V_{e}$ is the asset value of having a job, $w$ is the wage rate which is constant over the duration of employment, $\delta$ is the exogenous job separation rate and $V_{u}$ is the asset value of being unemployed. The employment value function is equal to the current utility $w$ plus the future value of becoming unemployed, which is actually a loss since $\left(V_{u}-V_{e}\right)$ is negative.

Similarly, the flow value of being unemployed is equal to:

$$
\rho V_{u}=b+\mu \int_{w^{r}}^{\infty}\left[V_{e}-V_{u}\right] d H(w)
$$

where $b$ represents the benefit level, $\mu$ denotes the exogenous arrival of job offers and $H(w)$ is the wage offer distribution. ${ }^{18}$ Again, the value function is equal to the current utility, which is the unemployment compensation $b$, plus the future value of finding a job, which occurs at rate $\mu$.

Unemployed workers can influence the exit rate from unemployment to work by choosing the reservation wage, i.e. the minimum wage that they require for accepting a job offer. From equation (1) the gain from being employed can be written as:

$$
V_{e}-V_{u}=\frac{w-\rho V u}{\rho+\delta},
$$

which implies that a job-seeker accepts a job offer if $V_{e}(w)>V_{u}$ or if $w>\rho V_{u}$. In a stationary environment, $\delta, \mu$ and $w$ are constant. In such an environment, the reservation wage $w^{r}$ is equal to the flow value of being unemployed: $w^{r}=\rho V_{U}$. Substituting (3) and $w^{r}=\rho V_{u}$ in (2), the reservation wage is implicitly defined by:

$$
w^{r}=b+\frac{\mu}{\rho+\delta} \int_{w^{r}}^{\infty}\left[w-w^{r}\right] d H(w)
$$

From equation 4 we can derive the following comparative statics. First, $\frac{\partial w^{r}}{\partial b}>0: w^{r}$ increases with unemployment benefits. Second, $\frac{\partial w^{r}}{\partial \mu}>0: w^{r}$ increases with the rate of incoming job offers $\lambda$. Third, $\frac{\partial w^{r}}{\partial \rho}<0: w^{r}$ decreases with individual's increasing focus on the present. Fourth, $\frac{\partial w^{r}}{\partial \delta}<0$ : $w^{r}$ decreases with increasing separation rate

In a stationary labor market, the job finding rate - or hazard rate - is defined as $\theta=\mu\left[1-H\left(w^{r}\right)\right]$, which is the product of the rate by which unemployed workers receive job offers and the probability that a given offer is acceptable. Variables that lead to an increase in the reservation wage lower the unemployment exit rate $\theta$ and increase the average duration of unemployment $D=\frac{1}{\mu[1-H(x)]}=\frac{1}{\theta}$.

From this we can derive the following comparative statics for the duration of unemployment $D$. First, $\frac{\partial D}{\partial b}>0: D$ increases with UI benefits; this is the standard disincentive effect of unemployment benefits on the exit rate of unemployment. Second, $\frac{\partial D}{\partial \rho}<0$ : $D$ decreases with individual's increasing focus on the present. Third, $\frac{\partial D}{\partial \delta}<0: D$ decreases with individual's instability of employment contracts. Fourth, $\frac{\partial D}{\partial \mu}$ : the effect is ambiguous since on the one hand $\mu$ increases $w^{r}$ (with negative effect on the exit rate) and increases $D$ while on the other hand, $\mu$ increases directly the exit rate, thus reducing reduces $D .{ }^{19}$

Allowing for search effort as an additional choice for the unemployed job-seeker does not alter the main effect of benefit receipt. An increase in benefit level $b$ not only increases the reservation wage $w^{r}$ but also leads to lower search effort, which further reduces the exit rate. Denoting the intensity of job 
search by the scalar $s$ the job offer arrival rate is $\mu=\alpha \mu(s)$ with $\mu^{\prime}>0$ and $\mu^{\prime \prime}<0$. The cost of search as a function of search effort is denoted by $c(s)\left(c^{\prime}>0, c^{\prime \prime}>0\right)$, which means that the instantaneous utility of an unemployed becomes $b-c(s)$. Furthermore, $\alpha$ is an indicator of the state of the labor market, which also affect the arrival rate of job offers. Unemployed workers can influence the exit rate from unemployment to work by choosing not only the reservation wage but also how much effort to exert in searching for a job. Using equation (4) and the optimal value of search effort satisfies the condition $\partial w^{r} / \partial s=0$ :

$$
c^{\prime}(s)=\frac{\alpha \mu^{\prime}(s)}{\rho+\delta} \int_{w^{r}}^{\infty}\left[w-w^{r}\right] d H(w)
$$

This shows the the optimal search effort is the one that equates the marginal cost of effort with the marginal benefit.

\section{Non-Stationary Search Model}

We now consider the non-stationary case in which the benefit level differs over the unemployment spell and benefit duration is limited (see Mortensen (1977) and Van den Berg (1990)). When the UI system defines a declining profile of benefit payments or a termination, the main theoretical prediction is an increasing job finding rate over the spell of insured unemployment. When the instantaneous income while unemployed declines over time we get that $b\left(t^{\prime}\right) \leq b(t)$ for all $t^{\prime} \geq t$, which results in a reduction of the value of unemployment with $V_{u}\left(t^{\prime}\right) \leq V_{u}(t)$. The decline in the value of unemployment over time and close to benefit exhaustion leads to a drop in the reservation wage with $w^{r}\left(t^{\prime}\right) \leq w^{r}(t)$, or alternatively a higher search intensity $s\left(t^{\prime}\right) \geq s(t)$, both of which results into a higher exit rate.

\section{Entitlement effects}

In most UI systems, benefit entitlement depends on previous employment experience, which is in contrast with the assumption of the basic model that all unemployed receive benefits. Typically, new entrants in the labor market and long-term unemployed are not entitled to receive unemployment insurance. Finding a job for this type of unemployed means also becoming entitled to unemployment insurance in case they lose their job in the future. The behavioral effect of this case has similarities with the non-stationary case we described above, where the unemployed close to benefit exhaustion experience a lower value of unemployment compared to those at the beginning of unemployment. In general, we can consider two different types of job-seekers. The first group consists of those who are entitled or are at the beginning of their unemployment spell who receive benefits $b$ with value of unemployment $V_{u}$. The second group consists of those who are close to benefit expiration or are not entitled for benefits with instantaneous income denoted by $b_{n}<b$ and value of unemployment $V_{u n}$. The flow value of being employed for a non-entitled unemployed is equal to:

$$
\rho V_{e}=w+\delta\left(V_{u}-V_{e}\right),
$$

which suggests that non-entitled unemployed become entitled for the full unemployment compensation once they find a job and become unemployed again in the future with probability $\delta$. Similarly, the flow value of being unemployed for a non-entitled unemployed is equal to:

$$
\rho V_{u n}=b_{n}+\mu \int_{w_{n}^{r}}^{\infty}\left[V_{e}(w)-V_{u n}\right] d H(w),
$$

where $b_{n}$ represents the flow of income different from unemployment benefits with $b_{n}<b$. For the entitled workers their reservation wage satisfies $w^{r}=\rho V u$. The reservation wage of the second group $w_{n}^{r}$ satisfies the equality $V_{e}\left(w_{n}^{r}\right)=V_{u n}$. Using these relations and equation (6) we can express the value of unemployment for the non-entitled workers as a function of the two reservation wages in the following way:

$$
\rho V_{u n}=\frac{\rho w_{n}^{r}+\delta w^{r}}{\rho+\delta} .
$$

Using equations (6), (7) and (8) we can express the reservation wage of the non-entitled unemployed as 
a function of the entitled ones:

$$
\rho w_{n}^{r}=(\rho+\delta) b_{n}-\delta w^{r}+\mu \int_{w_{n}^{r}}^{\infty}\left[w-w_{n}^{r}\right] d H(w) .
$$

This characterization shows that there is a negative relationship between the two reservation wages. An increase in the benefit level $b$ of the entitled workers that leads to an increase in their reservation wage $w^{r}$ is associated with a decline in the reservation wage of the non-entitled ones. This occurs because the immediate gain from the increase in the benefit level for the non-entitled is zero or very small for those close to benefit exhaustion, while the value of becoming qualified for benefits in the future increases. This entitlement effect increases the incentive to accept jobs for UI recipients close to benefits exhaustion and for those who are not entitled for unemployment benefits.

\section{Changes in $P B D$ and benefit levels}

The change in the behavior of job seekers over the spell of unemployment and the entitlement effect implies that individuals with different lengths of benefit entitlement would behave differently. For a given length of unemployment and for a given level of benefits, an increase in the potential benefit duration will lead to an increase of the reservation wage, and consequently to a rise in the average duration of unemployment. An increase in the potential benefit duration entails only a small immediate disincentive effect, that is, at the beginning of the unemployment spell. The largest effect of an increase in benefit duration is expected for unemployment durations close to the benefit expiration period before the change of the system. This is because the reservation wage at that time will be significantly higher under the new system with longer benefit duration compared to the system without a benefit extension, in which the reservation wage is at its lowest level.

An increase in the benefit level will also affect unemployed workers differently depending on their elapsed unemployment duration. Contrary to an extension of the benefit duration, an increase in the replacement rate has its largest effect at the start of the unemployment spell. For a recent unemployed worker, an increase in the benefit level will lower the exit rate from unemployment as a result of a higher value of unemployment. The job seeker will demand a higher wage before accepting a job offer. For an unemployed close to benefit exhaustion, a higher benefit level will lead to a higher exit rate due to the entitlement effect.

Theoretically, the overall effect of an increase in the generosity of benefits on the average duration of unemployment depends on the balance of two opposing effects. First, a higher amount of benefits and a longer benefit duration will lower the exit rate from unemployment. Second, for the non-eligible and for those close to benefit exhaustion, more generous benefits will create an incentive to find a job faster due to the entitlement effect. However, since the entitlement effect is second-order it is likely the disincentive effect that dominates so an increase in benefit generosity will lead to longer unemployment durations.

\section{Equilibrium Search Model}

In contrast to the search model, in the matching model frictions are modeled in a reduced form using a matching function $M=M(U, V)$, where $M$ is the flow of hirings, $U$ denotes the number of unemployed and $V$ the number of vacancies. The probability of filling a vacancy is $m(\theta)=M(U, V) / V$, which is a decreasing function of labor market tightness $\theta=V / U$. The probability for a job-seeker to find a job is $\theta m(\theta)=M(U, V) / U$, which is an increasing function of labor market tightness. Firms post vacancies, which are filled at the rate $m(\theta)$. The expected profit from a filled job is:

$$
r \Pi_{e}=y-w+\delta\left(\Pi_{v}-\Pi_{e}\right),
$$

where $y$ is the output, $w$ is the cost of labor and $\delta$ the exogenous separation rate. The expected profit from a vacant job is:

$$
r \Pi_{v}=-\kappa+m(\theta)\left(\Pi_{e}-\Pi_{v}\right)
$$

where $\kappa$ is the cost of posting a vacancy. With the assumption of free entry, $\Pi_{v}=0$ and in equilibrium the average cost of a vacant job must be equal to the expected profit from a filled job. Solving 10 and 11 for $\Pi_{e}$ we get:

$$
\frac{\kappa}{m(\theta)}=\frac{y-w}{\rho+\delta}
$$


which implies a negative relationship between labor market tightness and the wage. The behavior of workers is very similar to the basic search model with the value of unemployment be defined as:

$$
\rho V_{u}=b+\theta m(\theta)\left(V_{e}-V_{u}\right) .
$$

Wages are endogenously determined through wage bargaining, which is the mechanism that shares the rents created due to frictions between workers and firms. For both firms and workers the rents are the difference between what they could obtain through forming a match and the best outside opportunity. The sum of the rents creates the surplus to be shared, which is $S=V_{e}-V_{u}+\Pi_{e}-\Pi_{v}$. If $\beta$ represents the bargaining power of the worker (and $1-\beta$ is the bargaining power of the employer), the resulting negotiated wage is:

$$
w=\rho V_{u}+\beta\left(y-\rho V_{u}\right),
$$

which can be written as:

$$
w=b+\Gamma(\theta)(y-b),
$$

with $\Gamma(\theta)=\frac{\beta[\rho+\delta+\theta m(\theta)]}{\rho+\delta+\beta \theta m(\theta)}$ representing the overall bargaining weight of the workers, which does not only depend on the "direct" bargaining weight $\beta$ but is also increasing with labor market tightness $\theta$, and dependent on discount rate $\rho$ and job separation rate $\delta$.

The increase of unemployment benefits $b$ increases the value of unemployment for the job-seeker, which leads to an increase in the wage in the bargaining process. Since a higher wage lowers firms' expected profits (right hand side of equation 12), to restore equilibrium firms lower the average cost of vacancies by reducing the number of vacancies, which lowers $\theta$. To deduce the effect of an increase in unemployment benefits on unemployment, we consider the equilibrium in steady state in which the flows into unemployment equal the flows out of unemployment:

$$
\delta U=\delta L-\theta m(\theta) U=0,
$$

where $\delta \mathrm{U}$ denotes the change in the number of unemployed and $L$ denotes the number of employed. The stationary value of unemployment is then given by:

$$
u=\frac{\delta}{\delta+\theta m(\theta)},
$$

which generates a relationship between unemployment and vacancies, the Beveridge curve. It also shows that an increase in benefits and the corresponding drop in labor market tightness $\theta$ leads to an increase in the unemployment rate. 


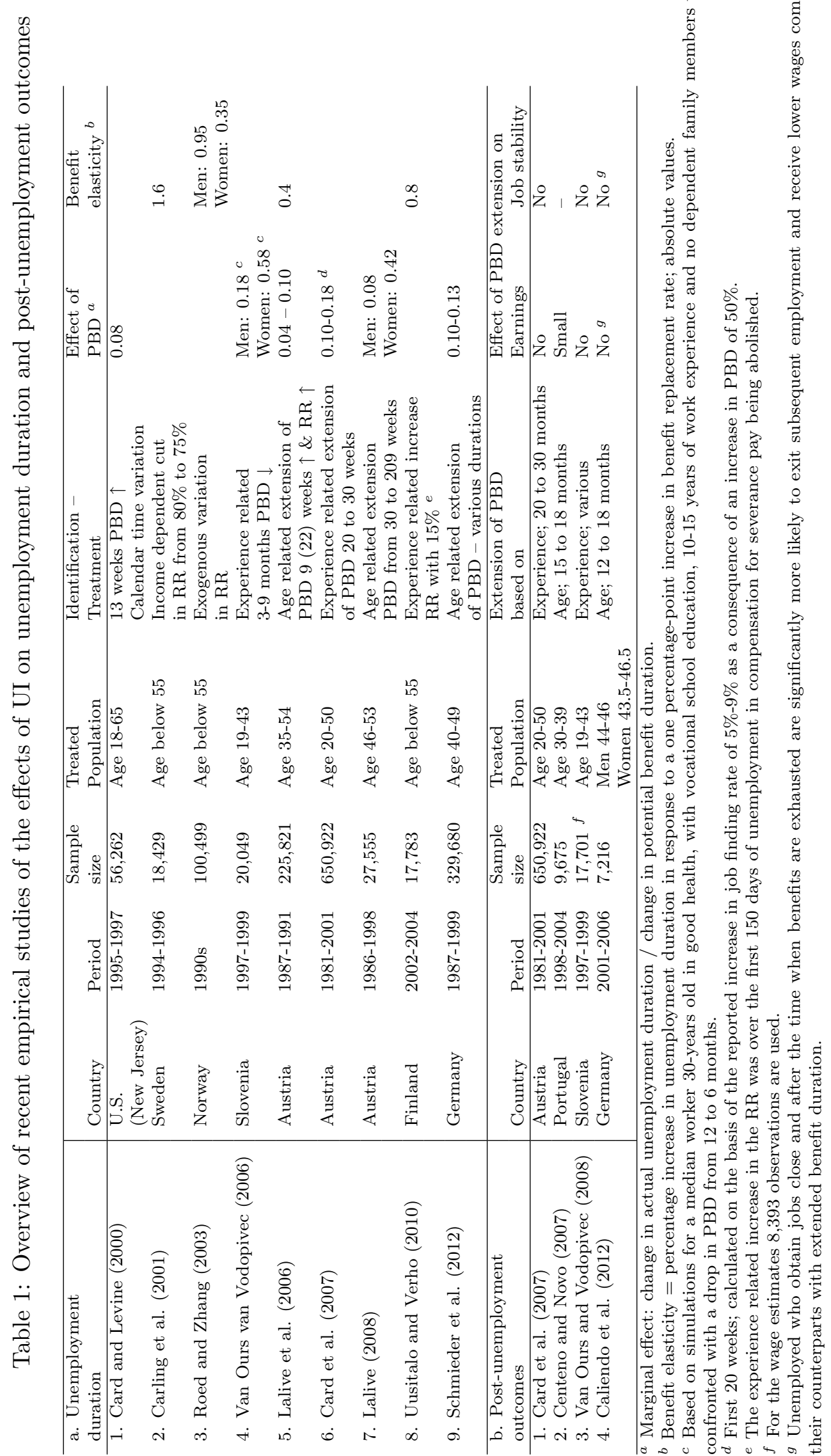


Table 2: Unemployment rates and employment rates prime age (25-54) and older individuals (55-64); long term unemployment; 2010

\begin{tabular}{|c|c|c|c|c|c|c|c|c|c|c|}
\hline & \multicolumn{4}{|c|}{ Men } & \multicolumn{4}{|c|}{ Women } & \multirow{2}{*}{\multicolumn{2}{|c|}{$\begin{array}{c}\text { Long term } \\
\text { Unemployment } \\
(\%)\end{array}$}} \\
\hline & \multicolumn{2}{|c|}{$\begin{array}{c}\text { Unemployment } \\
\text { rate }(\%)\end{array}$} & \multicolumn{2}{|c|}{$\begin{array}{l}\text { Employment } \\
\text { rate }(\%)\end{array}$} & \multicolumn{2}{|c|}{$\begin{array}{c}\text { Unemployment } \\
\text { rate }(\%)\end{array}$} & \multicolumn{2}{|c|}{$\begin{array}{l}\text { Employment } \\
\text { rate }(\%)\end{array}$} & & \\
\hline & $25-54$ & $55-64$ & $25-54$ & $55-64$ & $25-54$ & $55-64$ & $25-54$ & $55-64$ & Men & Women \\
\hline Australia & 3.7 & 3.7 & 87.2 & 68.6 & 4.4 & 2.6 & 71.9 & 52.8 & 20 & 16 \\
\hline Austria & 4.2 & 2.5 & 88.7 & 51.6 & 3.8 & 1.6 & 79.7 & 39.7 & 28 & 22 \\
\hline Belgium & 7.2 & 4.2 & 85.5 & 45.6 & 7.5 & 5.2 & 74.4 & 29.2 & 50 & 48 \\
\hline Canada & 7.3 & 7.5 & 83.9 & 63.3 & 6.4 & 5.6 & 77.0 & 53.5 & 13 & 11 \\
\hline Czech Republic & 5.2 & 6.5 & 90.5 & 58.4 & 8.0 & 6.5 & 73.4 & 35.5 & 43 & 43 \\
\hline Denmark & 7.1 & 6.8 & 85.9 & 62.7 & 5.9 & 4.6 & 80.6 & 52.5 & 21 & 17 \\
\hline Estonia & 17.6 & 19.0 & 75.4 & 52.2 & 12.9 & 14.1 & 73.9 & 54.9 & 48 & 41 \\
\hline Finland & 7.4 & 7.3 & 83.9 & 55.6 & 6.3 & 5.8 & 79.1 & 56.9 & 27 & 19 \\
\hline France & 7.1 & 6.9 & 87.1 & 42.1 & 8.5 & 6.4 & 76.7 & 37.5 & 42 & 39 \\
\hline Germany & 7.1 & 8.1 & 86.5 & 65.0 & 6.2 & 7.3 & 76.3 & 50.5 & 48 & 46 \\
\hline Greece & 9.4 & 6.2 & 85.3 & 56.5 & 15.5 & 6.5 & 61.1 & 28.9 & 39 & 50 \\
\hline Hungary & 10.6 & 8.2 & 77.9 & 39.6 & 10.1 & 7.3 & 67.1 & 30.1 & 51 & 50 \\
\hline Iceland & 7.0 & 5.1 & 86.9 & 83.9 & 5.6 & 3.5 & 80.6 & 77.0 & 23 & 19 \\
\hline Ireland & 15.9 & 10.5 & 75.6 & 58.4 & 8.5 & 5.0 & 66.0 & 43.0 & 54 & 38 \\
\hline Italy & 6.6 & 3.9 & 83.5 & 47.7 & 8.9 & 3.0 & 58.7 & 26.2 & 47 & 50 \\
\hline Japan & 4.9 & 6.1 & 91.4 & 78.8 & 4.8 & 3.3 & 68.2 & 52.1 & 45 & 25 \\
\hline Korea & 3.8 & 3.4 & 86.8 & 75.1 & 2.9 & 2.2 & 60.3 & 47.1 & 1 & 0 \\
\hline Luxembourg & 3.0 & 2.4 & 92.0 & 47.7 & 5.0 & 2.2 & 72.6 & 31.3 & 32 & 26 \\
\hline Netherlands & 3.6 & 4.1 & 90.0 & 64.8 & 3.6 & 3.7 & 79.3 & 43.3 & 28 & 27 \\
\hline New Zealand & 4.4 & 3.8 & 87.8 & 79.6 & 5.4 & 2.9 & 72.8 & 67.2 & 9 & 9 \\
\hline Norway & 3.5 & 1.8 & 87.1 & 72.2 & 2.6 & 0.9 & 82.2 & 65.0 & 11 & 8 \\
\hline Poland & 7.9 & 7.5 & 82.6 & 45.2 & 8.7 & 6.5 & 71.7 & 24.2 & 25 & 26 \\
\hline Portugal & 9.3 & 10.0 & 83.9 & 55.6 & 12.2 & 7.6 & 74.6 & 43.5 & 52 & 53 \\
\hline Slovak Republic & 12.4 & 9.6 & 81.4 & 54.1 & 13.3 & 11.0 & 70.1 & 28.8 & 58 & 61 \\
\hline Slovenia & 7.1 & 4.2 & 85.2 & 45.5 & 6.8 & 3.6 & 82.1 & 24.5 & 45 & 41 \\
\hline Spain & 18.1 & 14.3 & 75.7 & 54.7 & 19.2 & 13.8 & 63.2 & 33.2 & 45 & 41 \\
\hline Sweden & 6.0 & 6.2 & 88.0 & 74.3 & 6.3 & 4.4 & 82.0 & 66.8 & 18 & 15 \\
\hline Switzerland & 3.4 & 3.7 & 92.4 & 77.9 & 4.7 & 3.5 & 79.4 & 58.8 & 28 & 40 \\
\hline Turkey & 10.1 & 7.5 & 89.5 & 46.1 & 11.4 & 1.5 & 30.1 & 17.1 & 25 & 37 \\
\hline United Kingdom & 6.7 & 6.3 & 85.3 & 64.9 & 5.4 & 3.0 & 74.4 & 48.9 & 37 & 26 \\
\hline United States & 9.3 & 8.0 & 81.0 & 64.4 & 7.8 & 6.2 & 69.3 & 56.4 & 30 & 28 \\
\hline
\end{tabular}

Employment rate $=$ employment as a share of the population;

Unemployment rate $=$ unemployment as a share of the labor force $(=$ employment + unemployment $)$; Long-term unemployment as percentage of total unemployment.

Source: OECD Employment Outlook, 2011 


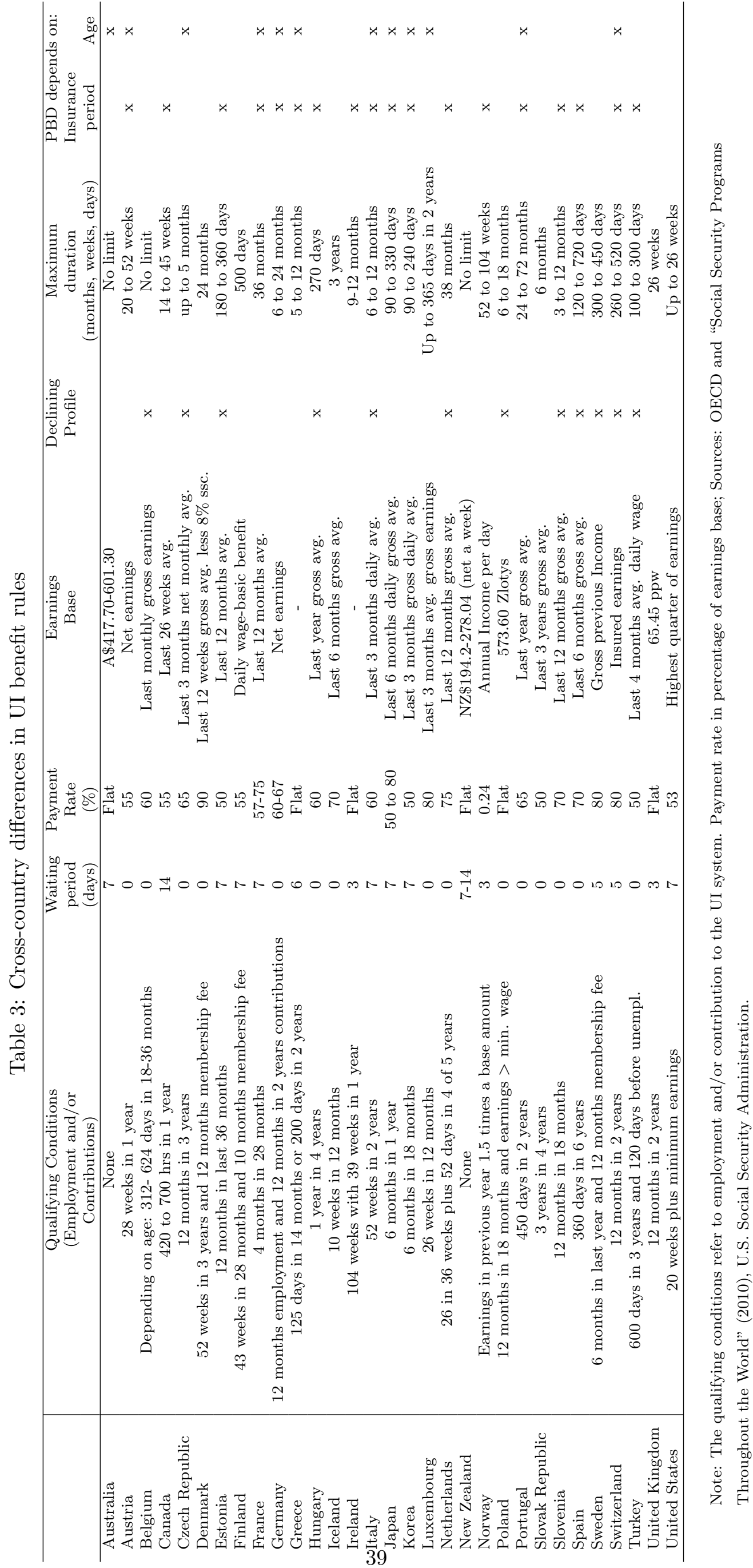

